\title{
Sobre la dimensión persuasiva de la máxima y del refrán en El Quijote y su contribución a la configuración del «efecto-personaje»
}

\author{
Juan Herrero Cecilia*
}

\section{INTRODUCCIÓN: OBJETIVOS Y CONCEPTOS PREVIOS}

Nuestro estudio tratará de poner de relieve la dimensión persuasiva y la finalidad comunicativa de la máxima y del refrán en la novela de Cervantes El ingenioso hidalgo don Quijote de La Mancha relacionando el recurso a la máxima y al refrán con las voces de don Quijote y Sancho como una manifestación significativa de su manera de pensar y de enfocar la realidad de la vida y del mundo, y como una estrategia eficaz que contribuye a producir en la mente del lector el «efecto-personaje». Podemos definir el «efecto-personaje» como la imagen global de la identidad de un personaje concreto que el texto construye y que el lector deduce a partir de la narración de sus actos y de las palabras y pensamientos que el narrador le atribuye. Las palabras y los pensamientos configuran en el texto el discurso del personaje y revelan su psicología, su sabiduría y su ideología personal. En efecto, la voz del personaje resuena en el texto con un tono particular y proyecta un ethos o una imagen de sí mismo que el lector percibe como un signo de la identidad moral con la que el autor le ha configurado. Esa imagen contribuye a pro-

\footnotetext{
* Universidad de Castilla la Mancha.
} 
ducir un pathos o efecto determinado de empatía en el lector (en forma de simpatía, de distancia o de rechazo) que funciona al mismo tiempo como un efecto más o menos fuerte de persuasión para entender la identidad que el personaje adquiere a través de su recorrido dentro del universo específico de la historia de ficción narrada en el texto. Según Jouve, el efecto-personaje puede adoptar tres orientaciones diferentes: el efecto-personal, el efecto-persona y el efecto-pretexto. Lo que aquí nos interesa resaltar es el «efecto-persona», que Jouve define de esta manera:
Para ser percibido como persona, el personaje debe estudiarse a través de las técnicas narrativas que suscitan la ilusión referencial (que producen la impresión que el personaje es un ser vivo) y de la manera según la cual el texto «programa» la proyección afectiva del lector. Para hacer «vivir» a su personaje, el narrador dispone de una serie de procedimientos (Jouve, 2010: 96. La traducción es nuestra).

Jouve llama «sistema de simpatía» al conjunto de procedimientos textuales que sirven para suscitar relaciones afectivas del lector con el personaje. Estas relaciones surgen a través del funcionamiento en el texto de tres códigos fundamentales:

a) El código narrativo y las modalidades de la perspectiva o punto de vista sobre la historia narrada.

b) El código afectivo o la manera de orientar la relación personaje-lector (si el lector accede a la interioridad del personaje se sentirá en simpatía con él. Lo mismo ocurre si le percibe dentro de una confrontación donde el deseo entra en conflicto con la prohibición o con el fracaso).

c) El código cultural o lo que Barthes llama los «códigos culturales» de una época, códigos que el autor va a hacer intervenir en la novela para orientar, desde el discurso del narrador y desde la interacción dialógica del discurso de los personajes, el sentido de los saberes, la relación (de armonía o de confrontación) entre las ideologías y los valores humanos y sociales. El lector puede sentirse cercano y ver con simpatía el tipo de valores que propugna o encarna un personaje determinado, o puede sentirse reacio o incompatible con ellos.

Es dentro de las relaciones dirigidas por los «códigos culturales» donde se inscribe, en el universo de la novela, el recurso a la máxima o al refrán por el narrador o por los personajes para defender un punto de vista o una manera de pensar o de sentir. Las relaciones dialógicas apoyadas en los «códigos culturales» guardan relación también con el concepto de polifonía que defiende Bajtín ${ }^{1}$ (entendido como la pluralidad de voces-conciencias que el autor ha

1. Sobre los conceptos de «dialogismo» y de «polifonía» en Mijail Bajtín, ver Herrero Cecilia (1992). 
representado libremente en el universo imaginario de una novela orientando el sentido de sus relaciones o de sus conflictos hacia una determinada dirección o conclusión).

El razonamiento o la opinión defendida con el apoyo de un refrán o por medio de la verdad universal que vehicula una máxima, no es otra cosa que la enunciación por un locutor de un determinado punto de vista equivalente a lo que Rabatel ${ }^{2}(2004,2008)$ llama el «punto de vista declarado» («point de vue asserté»). En la novela, el punto de vista declarado se manifiesta a través de los juicios y comentarios del narrador, y, especialmente a través del discurso de los personajes, en sus diálogos y monólogos. El punto de vista declarado remite a una cierta axiología o escala de valores, y puede ser observado en relación con el grado de legitimidad o de aceptabilidad de los argumentos aducidos por el locutor. En efecto, un discurso enunciado con convicción, con claridad de ideas (expresadas recurriendo a definiciones precisas, axiomas, sentencias, verdades de alcance general o universal) y formulado con un estilo atractivo, contribuye a generar una imagen positiva del sujeto enunciador (proyección de un ethos de lucidez, de sabiduría o de integridad moral). Por el contrario, un discurso enunciado con inseguridad, con confusión en la exposición de las ideas o con un razonamiento apoyado en estereotipos superficiales e impersonales, proyecta una imagen de superficialidad, de ignorancia o de una mentalidad cerrada al razonamiento crítico y personal.

Pero antes de entrar en el análisis de la dimensión persuasiva del discurso de don Quijote y de Sancho, queremos recordar aquí, aunque sea brevemente, que el refrán y la máxima ${ }^{3}$ son dos géneros bien diferentes del discurso proverbial o aforístico. En efecto, la verdad general que contiene el enunciado del refrán transmite una enseñanza práctica de tipo moral basada sobre la experiencia colectiva de la vida ordinaria y avalada por la voz anónima de la sabiduría popular e inmemorial ${ }^{4}$. A diferencia del refrán, cuya sabiduría

2. En sus estudios, Rabatel muestra que el discurso del relato conlleva una actividad de argumentación más o menos indirecta destinada a producir un efecto de persuasión en el lector a través de las diversas modalidades que adopta el «punto de vista» (PDV). Estas modalidades pueden ser de tres tipos: a) el «punto de vista narrado» muestra al lector la actitud del narrador (su mayor o menor empatía) ante los protagonistas del acontecimiento; b) el «punto de vista representado» funciona normalmente en los relatos narrados en $3^{\mathrm{a}}$ persona con «focalización interna» o escenificación de percepciones o de procesos mentales «frases sin palabras» atribuidos a un enunciador distinto del narrador; c) el «punto de vista declarado» muestra las opiniones y juicios del narrador y también las opiniones propias del discurso de los personajes por medio de las cuales un locutor defiende una tesis sobre un tema determinado (Rabatel, 2008: 81-115).

3. Aristóteles en un capítulo del libro II de la Retórica designa con el nombre de gnomé a la sentencia o máxima y dice que responde a «la reflexión y la composición de un hombre sabio» que presenta una verdad general sobre las acciones humanas. Frente a la gnomé, Aristóteles sitúa la paroimia (el proverbio o refrán) y la considera como una sentencia anónima perteneciente al legado de la sabiduría colectiva.

4. Sobre la estructuración del refrán y su funcionamiento enunciativo, semántico y argumentativo, se puede consultar la tesis de Gómez-Jordana Ferrari (2006), ver el resumen en Paremia, 16, 2007, pp. 169-174. 
proviene del pensamiento colectivo ancestral, la máxima ${ }^{5}$ es un enunciado generalizante que contiene un pensamiento completo, autónomo y suficiente, libremente elaborado por un locutor individual que ha reflexionado sobre el significado de la existencia y del destino humano. Por ser fruto de la reflexión y del pensamiento individual, el enunciado de la máxima ${ }^{6}$ se aleja de la opinión común y tiene un carácter analítico o crítico. Por eso, la verdad del enunciado de la máxima no es de la misma naturaleza que la verdad que ofrece el refrán. La moral práctica del refrán es el resultado de la experiencia colectiva de una comunidad. Esto justifica que su contenido sea verdadero, por convención, para todos los hablantes de la lengua dentro de la cual ha sido creado ${ }^{7}$. El enunciado de la máxima y el del refrán coinciden en que ambos presentan verdades generales formuladas de una manera categórica por medio de un presente que no se relaciona con el momento de la enunciación sino que tiene un carácter atemporal u omnitemporal, propio de lo que Adam llama la «énonciation proverbiale» (Adam, 1992: 23).

Como la máxima y el refrán son enunciados sentenciosos por medio de los cuales el locutor persigue una finalidad comunicativa de persuasión, los escritores integran con frecuencia este tipo de enunciados en el discurso del narrador o en el discurso de los personajes. Así ocurre, por ejemplo, en géneros como la fábula, el relato ejemplar, el cuento filosófico, o en determinados subgéneros de novela como la novela de tesis o novela filosófica, la novela de aprendizaje, la novela psicológica, etc.

\section{CARACTERÍSTICAS DEL DISCURSO DE DON QUIJOTE Y DEL DISCURSO DE SANCHO}

Además del trabajo de Lázaro Carreter (2001) titulado «Las voces del Quijote» -al que vamos a referirnos más adelante-, el funcionamiento del lenguaje en El Quijote, especialmente en lo que se refiere a las diferentes figuras retóricas, estilos o registros, ha suscitado otros estudios importantes como los de Helmut Hatzfeld (1972), Ángel Rosenblat (1971) o Edmundo Ernesto Delgado (2000). Numerosos y significativos son también los trabajos sobre el empleo de los refranes y de la fraseología. Uno de los primeros estudiosos fue, sin duda, el hispanista Louis Combet (1971), seguido pocos años después por la hispanista Monique Joly, autora de numerosos artículos, algunos de los cuales han sido

5. La «máxima» en su origen está asociada a la «sentencia» pues su nombre procede de maxima sententia (la sentencia mayor o la más general).

6. Nos referimos aquí, claro está, a la máxima creada por la reflexión de un sujeto individual, y no a la máxima «proverbializada», es decir a la máxima que tras haber sido formulada por la sabiduría de un sujeto individual, es aceptada dentro de una comunidad como un enunciado filosófico digno de ser repetido y citado por aquellos que aceptan su contenido como una verdad universal significativa.

7. Ver Schapira (1999: 80). 
recogidos en Études sur "Don Quichotte" (1996). El camino abierto por ambos hispanistas ha sido continuado por los trabajos de una serie de expertos como, por ejemplo, Colombi (1989), Bizzarri (2003), Tarnovska (2005), Rodríguez Valle (2005, 2008), Jesús Cantera, Julia y Manuel Sevilla (2005), etc.

Para nuestro estudio preferimos el término discurso en lugar de lengua o lenguaje, porque seguiremos un enfoque de tipo enunciativo basado en la pragmática textual propia del relato literario, es decir, en la interacción comunicativa estéticamente representada dentro de un texto narrativo. Desde esta perspectiva observaremos específicamente la dimensión persuasiva del refrán y de la máxima en el intercambio verbal de los diálogos entre don Quijote y Sancho. Pero antes de abordar este punto, consideramos necesario presentar primero una visión global sobre las características del discurso de estos dos personajes en El Quijote. Empezaremos señalando con Lázaro Carreter (2001: IX) que tanto don Quijote como Sancho constituyen una muestra de la «independencia creciente de los personajes, que introduce el Renacimiento en la literatura, porque sus voces se escapan del dominio absoluto que anteriormente ejercía el autor para afirmarse como «dueños de su albedrío». Cervantes ha logrado, en efecto, que la voz de don Quijote adquiera unas características peculiares porque sabe adoptar, según las circunstancias, tonos y estilos diferentes: el estilo ampuloso, arcaizante y altisonante de las novelas de caballerías (parodiado de una manera burlesca por el narrador), el estilo oratorio, el estilo de los consejos y «avisos de buen gobierno» (expresado por medio de sentencias, máximas, consejos o reflexiones personales), el estilo de la espontaneidad coloquial» lleno de «sencillez urbana o campestre [...] de vehemencia, de malicia espontánea» (Lázaro, 2001: XIX). Esta capacidad de adaptación a los diversos estilos existentes en el contexto cultural y literario de la época es, sin duda, una muestra de la complejidad del personaje.

Pero conviene señalar que la alternancia de tonos y de estilos revela también el desdoblamiento de la personalidad de don Quijote, que se mueve entre la locura inconsciente que le impulsa a querer convertirse en un nuevo caballero andante (influido por la lectura apasionada de las novelas de caballerías) y la cordura de un espíritu generoso, recto e idealista. Su sabiduría humanista (sobre la que trataremos más adelante) le hace atractivo ante la mirada del lector. El lector sentirá también una especial simpatía por el personaje de Sancho, porque, por su manera de expresarse, se muestra como un hombre sencillo y sincero que defiende la lógica del sentido común recurriendo a la sabiduría popular de los refranes, como argumento de autoridad, para hacer reflexionar a don Quijote cuando éste se lanza a emprender hazañas disparatadas imitando las gestas de los caballeros andantes. Usar y abusar de los refranes se convertirá en un signo característico del idiolecto de Sancho. Pero, como veremos, Sancho, influido por la fuerza del pensamiento humanista de don Quijote, no se va a quedar solamente con la sabiduría tradicional e impersonal del refrán, sino que llegará a desarrollar también su propia filosofía basada en el valor de la honradez individual, en la austeridad y en la imperturbabilidad del espíritu frente a las adversidades del destino. Al mismo tiempo, don Qui- 
jote va a aprender también de la sabiduría lúcida y realista de Sancho. Entre ellos irá surgiendo una relación de comprensión y de amistad que dará lugar a una complementariedad ideológica y existencial de la que surge una especial armonía de contrarios. Esta armonía viene a inscribirse dentro de la compleja polifonía que encierra El Quijote donde se contraponen personajes, valores y visiones del mundo bien diferentes, que el lector tendrá que interpretar. Como afirma Canavaggio (2009:12), Cervantes ha buscado por este camino «l'autonomie de la fiction narrative et, plus généralement, de la littérature de divertissement». La polifonía ideológica, unida al humor y a la ironía, constituye, en efecto, el valor estético de esta gran novela moderna de Cervantes.

Don Quijote se hace acompañar por Sancho como escudero o ayudante subalterno al que necesita para ejercer su misión de nuevo caballero andante. Pero, como afirma Lázaro, la relación entre don Quijote y Sancho va a adquirir pronto una importante dimensión psicológica e ideológica, porque se trata de una relación entre dos conciencias que se sitúan en oposición dialéctica ${ }^{8}$. En efecto, la palabra perspicaz de Sancho y su defensa de la lógica del sentido común operan frente a don Quijote como un contrapunto y un estímulo que le hace sacar hacia afuera sus conocimientos librescos sobre las hazañas de los héroes de sus lecturas, y también sus sentimientos ante las personas y las situaciones que aparecen en su camino, así como los principios y valores por los que se guía (que remiten a una sabiduría de signo humanista).

Cervantes ha caracterizado a Sancho como un espíritu sencillo, sincero y honrado que se vale de su conocimiento de los refranes populares para expresar sus opiniones de hombre inculto pero lleno de sentido común. No será, por lo tanto, un mero estereotipo del bobo rústico e ignorante que resulta gracioso porque deforma la pronunciación de ciertas palabras y no es capaz de hilar con lógica normal sus ideas. En efecto, como firma Lázaro Carreter (2001: XXI), «la voz diferente de Sancho en la polifonía quijotesca» fue el «gran desafío en que ha triunfado Cervantes», caracterizándolo por su manera peculiar de servirse de los refranes en el discurso. Pero no hay que olvidar, como ya hemos señalado, que, al contacto con la sabiduría de don Quijote, Sancho llegará a tener y a defender sus propios principios y convicciones. Lázaro valora de esta manera la evolución y transformación de ambos personajes:

\footnotetext{
Pero ocurrió que a Cervantes le fue creciendo la figura del tonto hasta hacerse tan importante como la de su señor. Y que este fue soltando lastre de locura hasta hacerse un tipo humano de máxima trascendencia. Basta observar de qué hablan ambos en sus primeras jornadas y el crecimiento progresivo del interés de sus temas (Lázaro Carreter, 2001: XXIV).
}

8. Lázaro Carreter ha percibido muy bien el sentido dinámico que adquiere dentro del relato la «oposición dialéctica» entre dos conciencias: «Tanto en la comedia áurea como en el relato, hacen falta dos conciencias compenetradas, pero en oposición dialéctica, de modo que una rebote en la otra, y permita revelar el pensamiento del personaje principal, dado que, normalmente, las miras del amo han de ser altas, sus hazañas valerosas y sus sentimientos elevados y sutiles» (Lázaro Carreter, 2001: XXIV). 
Y apoya esta observación en las palabras con las que Sancho, en el capítulo 22 de la Segunda parte, evalúa la opinión que don Quijote tiene de él por lo acertado de sus razonamientos y la opinión que él mismo tiene de la sabiduría de don Quijote:

Este mi amo, cuando yo hablo cosas de meollo y de sustancia suele decir que podría yo tomar un púlpito en las manos y irme por ese mundo adelante predicando lindezas; y yo digo dél que cuando comienza a enhilar sentencias y a dar consejos, no solo puede tomar un púlpito en las manos, sino dos en cada dedo, y andarse por esas plazas a ¿qué quieres, boca? ¡Válate el diablo por caballero andante, que tantas cosas sabes! ... No hay cosa donde no pique y deje de meter su cucharada (II, 22, 810).

\section{LA DIMENSIÓN PAREMIOLÓGICA EN EL QUIJOTE: EL EM- PLEO DE LA MÁXIMA Y DEL REFRÁN COMO ESTRATEGIA DISCURSIVA DE PERSUASIÓN}

Pasamos ahora a desarrollar el objetivo principal de nuestro estudio. Para ello observaremos cómo los dos personajes principales de la novela de Cervantes El Ingenioso hidalgo Don Quijote de La Mancha recurren al refrán y a la máxima empleando estas paremias como estrategias de persuasión en la interacción dialogada. Veremos también qué imagen de sí mismos proyectan en sus intervenciones y cómo esa imagen contribuye a la producción del efecto-personaje en la mente del lector. Conectando con lo que exponíamos al principio sobre el sistema de simpatía que pone en marcha el autor haciendo intervenir en la obra los códigos culturales, podemos afirmar que el recurso a la máxima y al refrán en el discurso de don Quijote y de Sancho remite a los códigos culturales de la época de Cervantes y marca cómo se sitúa cada personaje en relación con los saberes y en relación con el tipo de valores que asume o defiende en su propio discurso por medio de la máxima o por medio del refrán. Hay que tener en cuenta, por otro lado, que al introducir en el discurso del relato las opiniones de un personaje, el narrador puede mostrar una actitud de simpatía y de conformidad con él o una actitud de neutralidad, distancia, ironía, etc. Pero más allá del discurso del narrador y del discurso de cada personaje, la dimensión cultural e ideológica del refrán y de la máxima remiten a la sabiduría del autor y a su manera de situarse frente a los discursos ideológicos de su tiempo a través de las diversas voces que dialogan o se enfrentan dentro del texto.

La evolución de la personalidad de don Quijote y de la personalidad de Sancho se produce en buena medida dentro de la interacción dialogada. Es,

9. Las referencias y citas de Don Quijote de La Mancha se harán siguiendo la edición de Francisco Rico (2001). Se indicará con (I) la Primera Parte y con (II) la Segunda; luego el número del capítulo y finalmente el número de la página. Ejemplo: I, 19, 135. 
en efecto, en los diálogos donde Sancho se apoya en la sabiduría popular e inmemorial de los refranes y donde aprenderá también a expresar su sabiduría personal influido por la palabra culta de don Quijote. Este se mantendrá inflexible cuando defiende la existencia y las hazañas de los caballeros andantes. Pero en otros asuntos se mostrará lúcido y comprensivo. En algunas ocasiones sus intervenciones constituyen toda una muestra de sabiduría profunda, de clarividencia y de ingenio. Es entonces cuando recurre al género aforístico de la sentencia o de la máxima para expresar con cierta solemnidad, de una manera libre y personal, unos principios o unos pensamientos (sobre la libertad, el amor, la hermosura, la fortuna, el heroísmo, etc.) que muestran un ethos de perspicacia crítica o de autenticidad moral. Algunos estudiosos de la obra de Cervantes han relacionado esta imagen de su carácter moral con la sabiduría humanista que había guiado la labor renovadora y crítica de los erasmistas en el campo de la fe y de la vida cristiana ${ }^{10}$. Sobre esta cuestión conviene, sin embargo, hacer ciertas precisiones. En efecto, frente a la tesis de Américo Castro que habla de un erasmismo heterodoxo en el pensamiento de Cervantes, y el enfoque de Antonio Vilanova que defiende la idea de que Elogio de la locura de Erasmo no sólo es una de sus principales fuentes de inspiración, «sino el estímulo decisivo que le había llevado a encarnar las figuras de Sancho Panza y Don Quijote, los extremos contrapuestos de la necedad y de la locura (Vilanova, 1989: 79), debemos señalar, por otro lado, el enfoque de Alban K. Forcione (1982), que ha estudiado cuatro novelas ejemplares de Cervantes. De su estudio deduce que Cervantes era un humanista cristiano influido por las ideas renovadoras de Erasmo, pero sin que ello suponga una orientación heterodoxa sino desde una perspectiva más acorde con el pensamiento oficial en la España de la época. En esta línea, Anthony Close (2004: LXXXVII) afirma que «los residuos de pensamiento erasmista que pueden tal vez hallarse en los escritos de Cervantes y sus coetáneos cobran un sentido muy distinto al que tenían medio siglo antes por estar encuadrados en un contexto ideológico postridentino».

Volviendo ahora a resaltar la importancia de la sentencia y de la máxima en el discurso de don Quijote, conviene señalar también que la sabiduría breve (analítica y crítica) que encierran los géneros proverbiales o aforísticos había sido puesta de relieve por Erasmo de Rotterdam en sus Adagia ${ }^{11}$. Se-

10. La actitud crítica y reformista de Erasmo frente a la religión cristiana se sitúa dentro del contexto de la búsqueda de la «humanitas» (es decir, la plena realización intelectual, religiosa, moral y estética del ser humano) por los sabios renacentistas, pues como afirma Canavaggio, «les humanistes [...] appliquent les méthodes de la philologie aux textes sacrés; ainsi en viennent-ils inévitablement à mettre en question l'interprétation traditionnelle de la Bible, une attitude qui les conduit à un questionnement de plus large portée, celui de l'orthodoxie religieuse officielle» (2009: 4). La influencia de Erasmo sobre Cervantes ha sido defendida por Américo Castro (1957) y por Antonio Vilanova (1989). Marcel Bataillon, por su parte, ha estudiado la influencia de Erasmo en España y la cuestión del humanismo erasmista en Erasmo en España (1950) y en Erasmo y el erasmismo (1977).

11. Adagios (Adagiorum collectanea). Primera edición en 1500, París; edición corregida y aumentada por el autor en $1508,1518,1520,1523,1526,1528,1533$ y 1536 . Al final de su vida Erasmo 
gún Colón Domenech (2004), un buen número de los adagios de Erasmo fue recogido por el gramático español Lorenzo Palminero en De vera \& facile imitatione Ciceronis (1560). Por otro lado, el interés de Sancho por apoyar sus argumentos de hombre inculto en la sabiduría popular de los refranes, es una muestra de la apertura de espíritu de Cervantes y de su acercamiento a la cultura popular tradicional que había atraído el interés de los humanistas paremiólogos del Renacimiento español, como por ejemplo Hernán Núñez, Mal Lara, Covarrubias, y Correas ${ }^{12}$.

\section{MODALIDADES, OBJETIVOS Y EFECTOS DEL EMPLEO DEL REFRÁN ${ }^{13}$ EN EL DISCURSO DE SANCHO}

Como ya hemos dicho más arriba, el rasgo más característico del idiolecto de Sancho es el uso frecuente que va a hacer de los refranes (voz de la sabiduría popular tradicional) y su manera peculiar de introducirlos en su discurso como argumento de autoridad frente a la sabiduría culta de don Quijote. Hay que señalar sin embargo que Cervantes (como observa Lázaro Carreter) tardó cierto tiempo en forjar la personalidad de Sancho asociándola a su manera de recurrir a los refranes, porque el primer refrán citado por él no aparece hasta el capítulo 19 y lo hace de esta manera: "Como dicen, váyase el muerto a la sepultura y el vivo a la hogaza» (I, 19, 207). Aquí Sancho no cita este refrán como algo que conoce bien sino apoyándose en un dicho al que la gente suele recurrir. Pero poco a poco, Sancho hará del refrán una especie de arma dialéctica (sin respetar a veces la noción de su coherente aplicabilidad) con la que se enfrentará, en nombre de la lógica del sentido común, a la oratoria visionaria y libresca de don Quijote para tratar de disuadirle de emprender aventuras temerarias, o simplemente para justificar su visión realista de las cosas apoyándose en la sabiduría popular. Por eso el narrador no duda en resaltar ante el lector esta característica peculiar de la palabra y de la personalidad de Sancho: «Y en lo que él se mostraba más elegante y memorioso era en "traer refranes", viniesen o no viniesen a pelo de lo que trataba, como se habrá visto y se habrá notado en el discurso desta historia» (II, 12, 720). Según Lázaro Carreter, citar y ensartar refranes se va a convertir en una propiedad del lenguaje de Sancho consustancial con su persona:

había recopilado 4.151 adagios con comentarios histórico-filológicos.

12. Ver a este respecto: Agustín Redondo (1979) y, dentro de este libro, el artículo de Maxime Chevalier, «Proverbes, contes folkloriques et historiettes traditionnelles dans les œuvres des humanistes parémiologues», pp. 105-118.

13. Existen actualmente en Internet algunas direcciones donde se han recogido los refranes y las frases proverbiales que aparecen en El Quijote. Señalamos aquí las siguientes: El Refranero en Don Quijote (lista de los refranes citados): http:/tierrasdeabadengo.es/departamentos/web\%20depto_lengua/refranes_quijote.htm. El Refranero en Don Quijote: http://www.nulladiessinnemeditatione.com/ refranero_en_don_quijote.htm. 
Y así ha pasado Panza a la historia de nuestra lengua artística: como portador de «un costal de refranes en el cuerpo», según dictamen del cura (II, 50, 1043), aunque ello no figurara en el proyecto inicial de su creador. Al construir así al escudero, al imponerle un uso del refrán tan distinto del que hacen otros personajes, la voz de Sancho ingresa con un timbre diferenciado y potente en el gran conjunto polifónico del Quijote (Lázaro Carreter, 2001: XXIII).

Así el uso peculiar del refrán en boca de Sancho será percibido por el lector como un rasgo característico de su identidad (efecto-personaje). Cervantes refuerza este rasgo con la manía de abusar de los refranes que Sancho va a mostrar en muchas ocasiones. Lo cual produce además un efecto de comicidad que hace más atractivo al personaje. Así, cuando don Quijote le reprende por enésima vez el abuso de los refranes, Sancho es consciente de que debería corregir esa manía, pero lo ve difícil: "No sé qué mala ventura es esta mía -respondió Sancho-, que no sé decir razón sin refrán, ni refrán que no me parezca razón; pero yo me enmendaré, si pudiere» (II, 71, 1204). Esto quiere decir que, para Sancho, el refrán vale como argumento para justificar una razón (opinión o punto de vista) y que el refrán es ya en sí mismo una razón (una verdad que conviene tener en cuenta). Ahora bien, ya sean como argumentos (topos) o como verdades propias de la sabiduría popular, los refranes con los que Sancho justifica sus planteamientos no constituyen una reflexión o un pensamiento elaborado por él de una manera personal para proclamar una verdad universal sino que se trata más bien de la aceptación de verdades o normas previamente proclamadas por la sabiduría colectiva. La concepción del refrán como sentencia proclamada por la voz anónima de la sabiduría colectiva y apoyada en la experiencia misma de la vida, es la que Cervantes (siguiendo a los paremiólogos del Renacimiento español) defiende a través de la voz de don Quijote que sabe diferenciar entre la sabiduría práctica de los refranes populares y la sabiduría culta y crítica del pensamiento individual enunciado como verdad universal bajo la forma de la máxima o de la reflexión filosófica. La defensa de la sabiduría del refrán aparece, por ejemplo, en el capítulo 21 de la Primera parte, cuando don Quijote le dice a Sancho: «Paréceme, Sancho, que no hay refrán que no sea verdadero, porque todos son sentencias sacadas de la mesma experiencia ${ }^{14}$, madre de las ciencias todas, especialmente aquel que dice «donde una puerta se cierra, otra se abre» (I, 21, 223). Don Quijote cita aquí un refrán que le sirve para justificar el hecho de emprender una nueva aventura: la recuperación del famoso yelmo de Mambrino. Al final de la Segunda parte, don Quijote precisará mejor su concepción del refrán

14. Una concepción similar del refrán, como sentencia sacada de la experiencia ancestral, aparece en las palabras que cita el cautivo cuando empieza la narración de su historia: «Hay un refrán en nuestra España, a mi parecer muy verdadero, como todos lo son, por ser sentencias breves sacadas de la luenga y discreta experiencia» (I, 39, 451). 
insistiendo ahora en la pertinencia comunicativa y argumentativa de su aplicación ${ }^{15}$, es decir, en el hecho de que un refrán sólo puede ser citado por el locutor cuando resulte coherente y apropiado para defender una opinión o un punto de vista:

-Mira, Sancho -respondió don Quijote-: yo traigo los refranes a propósito, y vienen cuando los digo como anillo en el dedo, pero tráeslos tú tan por los cabellos, que los arrastras, y no los guías; y si no me acuerdo mal, otra vez te he dicho que los refranes son sentencias breves, sacadas de la experiencia y especulación de nuestros antiguos sabios ${ }^{16}$, y el refrán que no viene a propósito antes es disparate que sentencia (II, 67,1178).

Don Quijote ya había insistido en varias ocasiones ante Sancho sobre la congruencia en el empleo del refrán, como se puede ver, por ejemplo, en el capítulo 43 de la Segunda parte ${ }^{17}$. La transgresión de la pertinencia comunicativa y de la aplicabilidad en el empleo del refrán producirá en el lector une efecto de choque y de comicidad al que ya hemos hecho alusión. La comicidad es más intensa cuando Sancho recurre a la acumulación o sarta de refranes.

\subsection{El empleo del refrán por Sancho como defensa de la lógica del sentido común en oposición dialéctica a la lógica visionaria de don Quijote}

En sus discusiones con don Quijote, Sancho defiende la lógica del sentido común, y para ello se apoya en los refranes populares (su único caudal ${ }^{18}$ cultural) como arma dialéctica para hacer frente a las opiniones y decisiones temerarias que quiere imponer don Quijote guiado por el deseo de ser fiel a su ideal de nuevo caballero andante. El espíritu perspicaz de Don Quijote percibe claramente que Sancho, por medio de los refranes, le dispara de vez en cuando unas saetas especiales que apuntan a un blanco determinado (convencerle con argumentos de peso sobre la necesidad de hacer algo concreto); y así se lo hace ver en alguna ocasión:

15. La pertinencia en la cita o aplicación del refrán es la misma noción que Sonia Fournet-Perot (2009:3) designa como la «aplicabilidad» del enunciado del refrán a un contexto particular de interacción verbal.

16. Esta definición del refrán como sentencia breve que procede de «nuestros antiguos sabios» se acerca a la que propone Aristóteles en La Retórica donde designa al refrán o proverbio con el término paroimia considerándolo como un enunciado anónimo perteneciente al legado de la sabiduría colectiva.

17. -«También, Sancho, no has de mezclar en tus pláticas la muchedumbre de refranes que sueles, que, puesto que los refranes son sentencias breves, muchas veces los traes tan por los cabellos, que más parecen disparates que sentencias» (II, 43, 974).

18. En una discusión con don Quijote, que le reprocha el abuso de los refranes, Sancho le responde que no tiene «otro caudal alguno sino refranes y más refranes» (II, 43, 977). 
[...] Pero no importa nada, pues vuesa merced me ha entendido.

-Y tan entendido -respondió don Quijote-, que he penetrado lo último de tus pensamientos y sé al blanco que tiras con las innumerables saetas de tus refranes (II, 7, 681).

Pero a pesar de los ruegos de Sancho y de sus argumentos basados en la lógica del sentido común, avalada por la sabiduría que contienen los refranes, don Quijote no da su brazo a torcer y se suele mantener firme en sus decisiones, porque él se mueve siguiendo el código heroico de los valores de los caballeros andantes, es decir aplicando la lógica visionaria que ha asimilado en sus apasionadas lecturas. Así ocurre, por ejemplo, en el siguiente enfrentamiento dialéctico:

Señor, yo no sé por qué quiere vuestra merced acometer esta tan temerosa aventura $[\ldots]$ yo he oído predicar al cura de nuestro lugar, que vuestra merced bien conoce, que quien busca el peligro perece en él; así que no es bien tentar a Dios acometiendo tan desaforado hecho, donde no se puede escapar sino por milagro (I, 20, 209-210) ${ }^{19}$.

Aquí Sancho intenta reforzar el valor argumentativo del refrán citado atribuyéndoselo a la autoridad del «cura de nuestro lugar». El ejemplo siguiente ilustra muy bien cómo Sancho se sirve de un refrán muy oportuno para discutir con don Quijote, manteniendo un punto de vista totalmente opuesto al que éste defiende cuando trata de justificar la veracidad de lo que había visto en la cueva de Montesinos:

- ¿Y duermen por ventura los encantados, señor? -preguntó Sancho.

-No, por cierto - respondió don Quijote-; a lo menos, en estos tres días que yo he estado con ellos, ninguno ha pegado el ojo, ni yo tampoco.

-Aquí encaja bien el refrán -dijo Sancho- de «dime con quién andas: decirte he quién eres». Ándase vuestra merced con encantados ayunos y vigilantes: mirad si es mucho que ni coma ni duerma mientras con ellos anduviere. Pero perdóneme vuestra merced, señor mío, si le digo que de todo cuanto aquí ha dicho, lléveme Dios, que iba a decir el diablo, si le creo cosa alguna. (II, 23, 825).

Sancho puede llegar incluso a citar un refrán para obedecer a don Quijote (porque no hay manera de convencerle), pero sin dejar de manifestar al mismo tiempo que no comparte el punto de vista de su amo, como ocurre, por ejemplo, en la aventura del barco encantado» (II, 29, 868-869).

19. En las citas de nuestro estudio señalaremos con letra cursiva los refranes y las máximas que el autor pone en boca de don Quijote y de Sancho. 


\subsection{El humor y el efecto de comicidad por medio de la acumulación o sarta de refranes en boca de Sancho}

Además del empleo argumentativo de la sabiduría popular del refrán como arma dialéctica para hacer frente a la lógica visionaria de don Quijote, Sancho recurre de vez en cuando a la acumulación o sarta de refranes soltados de golpe y enfilados uno tras otro para defender con más fuerza una opinión o un punto de vista determinado que desea hacer compartir por su interlocutor. Como se trata de refranes aparentemente inconexos soltados de una manera abrupta y chocante, este tipo de intervención se convierte en un procedimiento de humor grotesco ${ }^{20}$. Por medio de esta estrategia enunciativa, Cervantes logra que la voz de Sancho le resulte simpática y graciosa al lector, porque la sarta de refranes se presenta como una ruptura de la pertinencia comunicativa y produce un efecto de grotesca hilaridad, pudiéndose hablar aquí de extra-aplicabilidad (ver el estudio de Fernot-Perot, 2009:11), en el empleo discursivo del refrán. El efecto de humor grotesco resulta más palpable porque esta manía de Sancho desconcierta a don Quijote y le hace enfadarse con su escudero. Este procedimiento aparece por primera vez, en el capítulo 25 de la Primera parte. Aquí don Quijote defiende el honor de la reina Madásima, que, según sus lecturas, había sido acusada por el vulgo de estar amancebada con Elisabat, su ayo y su médico. Y le dice a Sancho: " ¡Y mienten, digo otra vez, y mentirán otras doscientas, todos los que tal pensaren y dijeren!». A lo cual, Sancho responde de la manera siguiente:

\section{Ni yo lo digo ni lo pienso -respondió Sancho-. Allá se lo hayan; con su pan se lo coman. Si fueron amancebados o no, a Dios habrán dado la cuenta. De mis viñas vengo, no sé nada; no soy amigo de saber vidas ajenas; que el que compra y miente, en su bolsa lo siente. Cuanto más, que desnudo nací, desnudo me hallo: ni pierdo ni gano. Mas que lo fuesen, ¿qué me va a mí? y muchos piensan que hay tocinos, y no hay estacas. Mas, ¿Quién puede poner puertas al campo? Cuanto más, que de Dios dijeron (I, 25, 273).}

Aquí el lector percibe fácilmente un rasgo de humor grotesco porque, con el exceso de refranes, se pierde el hilo de la argumentación y parece no respetarse la noción de aplicabilidad al contexto de comunicación. Don Quijote queda desconcertado porque le parece que Sancho dice necedades alejándose de toda coherencia lógica. Pero tal vez se sienta molesto porque Sancho se ha atrevido a dar su propia opinión sin someterse a las «reglas de caballería» (I, 25, 273).

Sancho recurrirá a la sarta de refranes en varias ocasiones. Hay que señalar, sin embargo, que en el capítulo 5 de la 2. ${ }^{a}$ parte, el torrente de refranes

20. El humor grotesco de Sancho guarda relación de alguna manera con el humor carnavalesco de la cultura cómica popular, que Bajtín ha estudiado en la obra de Rabelais. Ver Bajtín (Barral, 1974; Alianza, 1987). 
va acorrer a cargo de Teresa Panza. En efecto, en el diálogo entre Sancho y su mujer, Sancho aparece asumiendo en su discurso el papel de don Quijote, y Teresa asume el de Sancho. Así surge un efecto de comicidad por lo inesperado del estilo. Por eso, el narrador señala que «Llegando a escribir el traductor desta historia este quinto capítulo, dice que le tiene por apócrifo» (II, 5, 663). La sorpresa se produce porque la sarta de refranes sale ahora de la boca de Teresa como arma dialéctica para contra-argumentar la intención de su marido de casar a Mari Sancha con alguien importante, si él llega a ser gobernador. Ante la cascada de refranes que acompañan sus razonamientos, Sancho, asumiendo ahora el rol que frente a él ejercía don Quijote, se verá obligado a reprochar a su mujer la confusión en los planteamientos: «iVálate Dios, la mujer, y qué de cosas has ensartado unas en otras, sin tener pies ni cabeza! ¿Qué tiene que ver el Cascajo, los broches, los refranes y el tono con lo que yo digo?» (II, 5, 668)

Pero normalmente será Sancho el que va a ensartar y entrelazar refranes acompañando a sus razonamientos, como ocurre en II, 7; II, 14; II, 34; II, 43 (en este capítulo el procedimiento se repite varias veces) y en II, 67. En una de estas ocasiones, la sarta de refranes viene a replicar precisamente a un refrán que ha enunciado don Quijote. Sancho contra-argumenta soltando tres refranes que parecen no tener relación, pero acto seguido él mismo explica el razonamiento implícito que, por vía metafórica, contienen esos refranes. De esta manera refuerza su argumentación produciendo el desconcierto y el enfado en don Quijote:

Plega a Dios, Sancho, que así sea, porque del dicho al hecho hay gran trecho.

-Haya lo que hubiere -replicó Sancho-, que al buen pagador no le duelen prendas, y más vale al que Dios ayuda que al que mucho madruga, y tripas llevan pies, que no pies a tripas; quiero decir que si Dios me ayuda, y yo hago lo que debo con buena intención, sin duda que gobernaré mejor que un gerifalte. ¡No, sino pónganme el dedo en la boca, y verán si aprieto o no!

- ¡Maldito seas de Dios y de todos sus santos, Sancho maldito -dijo don Quijote-, y cuándo será el día, como otras muchas veces he dicho, donde yo te vea hablar sin refranes una razón corriente y concertada! (II, 34, 916).

Aunque la acumulación de refranes sea un procedimiento específico del discurso de Sancho, don Quijote puede permitirse alguna vez recurrir a esta estrategia de persuasión para demostrarle a Sancho que él también es capaz de arrojar refranes para reforzar sus argumentos: «Hablo de esta manera, Sancho, por daros a entender que también como vos sé yo arrojar refranes como llovidos» (II, 7, 682). 


\subsection{Más allá de la comicidad: el ethos de perspicacia de Sancho}

Como demuestra Fournet-Perot (2009: 11-13), más allá de la aparente incoherencia y del humor grotesco que manifiesta la acumulación de refranes por Sancho en el ejemplo del capítulo 25 de la Primera parte (al que nos hemos referido más arriba ${ }^{21}$ ), se puede percibir, si se analiza con detenimiento, una coherencia argumentativa que busca el refuerzo de su razonamiento por medio de la insistencia. En efecto, Sancho no hace otra cosa que reforzar su opinión con lucidez ante don Quijote avanzando en su razonamiento por la vía de la asociación de ideas que no resultan perceptibles a primera vista. De su discurso se desprende un ethos de agilidad mental, que le diferencia de la imagen estereotipada del bobo o del rústico ignorante pero gracioso. Después de explicar la coherencia argumentativa que manifiestan los refranes hilados de Sancho en este ejemplo, Fournet-Perot llega a la siguiente conclusión:

En résumé, ce que dit Sancho, c'est qu'il ne sait rien à propos de cette histoire, qu'il ne ment pas, qu'en pareil cas l'on doit se méfier des apparences et, enfin, qu'il est impossible d'empêcher les médisances. Bref, il désire que son maître, au vu de son ignorance et de sa franchise, ne s'en prenne pas à lui, qu'il réalise son impuissance à lutter contre les apparences trompeuses et les ragots et, en conséquence, qu'il retrouve son calme. Ce qui, de prime abord, semblait absurde ne l'est pas réellement (Fournet-Perot, 2009:12).

Podemos afirmar entonces que la acumulación de refranes por parte de Sancho además de revelar un rasgo de su identidad (efecto-personaje) y de producir un efecto de humor ${ }^{22}$, contribuye también a resaltar ante el lector un ethos moral de perspicacia y de agudeza mental. Un ethos de perspicacia y también de honradez puede percibirse en el ejemplo siguiente donde Sancho responde a don Quijote acumulando varios refranes, pero los explica acto seguido para defender la tesis de que un gobernador merece ser respetado y nadie puede burlarse de él. De sus explicaciones se desprende una imagen de hombre valiente, sincero y recto que está decidido a hacer valer la autoridad que le corresponde a un gobernador:

-Ese Sancho no eres tú -dijo don Quijote-, porque no solo no eres buen callar, sino mal hablar y mal porfiar; y, con todo eso, querría saber qué cuatro refranes te ocurrían ahora a la memoria, que venían aquí a propósito, que yo ando recorriendo la mía, que la tengo buena, y ninguno se me ofrece.

21. «[...] Allá se lo hayan; con su pan se lo coman. Si fueron amancebados o no, a Dios habrán dado la cuenta. De mis viñas vengo, no sé nada; no soy amigo de saber vidas ajenas; que el que compra y miente, en su bolsa lo siente. Cuanto más, que desnudo nací, desnudo me hallo: ni pierdo ni gano, etc.» (II, 25, 273).

22. Sobre el humor y la risa en «El Quijote», ver el artículo de Trueblood (1984). 
-¿Qué mejores -dijo Sancho- que «entre dos muelas cordales nunca pongas tus pulgares», y «a idos de mi casa y qué queréis con mi mujer, no hay responder», $y$ «si da el cántaro en la piedra o la piedra en el cántaro, mal para el cántaro», todos los cuales vienen a pelo? Que nadie se tome con su gobernador ni con el que le manda, porque saldrá lastimado, como el que pone el dedo entre dos muelas cordales, y aunque no sean cordales, como sean muelas, no importa; y a lo que dijere el gobernador, no hay que replicar, como al «salios de mi casa y qué queréis con mi mujer». Pues lo de la piedra en el cántaro un ciego lo verá. Así que es menester que el que ve la mota en el ojo ajeno vea la viga en el suyo, porque no se diga por él: "espantose la muerta de la degollada»; y vuestra merced sabe bien que más sabe el necio en su casa que el cuerdo en la ajena (II, 43, 977-978) ${ }^{23}$.

\subsection{Un refrán como lema existencial de Sancho: «desnudo nací, desnudo me hallo: ni pierdo ni gano»}

Si se observa la evolución de la manera de pensar de Sancho y los rasgos que caracterizan su identidad moral reflejada en su propio discurso, resulta muy significativo el empleo que hace del siguiente refrán: «Desnudo nací, desnudo me hallo: ni pierdo ni gano». Sancho enuncia por primera vez este refrán en el capítulo 25 de la Primera parte (dentro de la sarta de refranes que hemos citado más arriba), pero volverá a emplearlo en varias ocasiones identificándose con el sujeto enunciador que asume en primera persona el contenido proclamado en el enunciado. El ethos discursivo o la imagen que el enunciador proyecta en este enunciado es una imagen de desprendimiento, austeridad, sencillez e imperturbabilidad, muy próxima del estoicismo y de la resignación cristiana. En realidad, según Rodríguez Valle (2008: 145), éste sería uno de los refranes creados por Cervantes, porque no aparece citado en los refraneros anteriores a la publicación del Quijote de 1605. Más que un refrán, se trata de una sentencia que Cervantes pone en boca de Sancho en la cual una verdad general queda asumida en primera persona como verdad personal. Rodríguez Valle (2008) muestra que esta sentencia procede de la Biblia, en concreto del libro de Job: «Y dijo: Desnudo salí del vientre de mi madre, y desnudo volveré allá. El Señor me lo dio; el Señor me lo ha quitado; bendito sea el nombre del Señor» (Job: I, 21). Sancho elabora su sentencia inspirándose en las palabras de Job, pero modificando el contenido y adaptándolo a una situación de desprendimiento y de austeridad existencial proclamada «ahora y aquí»: «Desnudo nací,

23. La lógica argumentativa de insistencia por medio de la acumulación de refranes se puede ver también cuando Sancho ya se imagina que don Quijote y él van a dedicarse a vivir en el campo con los nombres del pastor Quijotiz y del pastor Pancino imitando a la «pastoral Arcadia», y dice: «Sanchica mi hija nos llevará la comida al hato. Pero, iguarda!, que es de buen parecer, y hay pastores más maliciosos que simples, y no querría que fuese por lana y volviese trasquilada [...] y quitada la causa, se quita el pecado, y ojos que no ven, corazón que no quiebra, y más vale salto de mata que ruego de hombres buenos» (II, 67, 1177). 
desnudo me hallo: ni pierdo ni gano». Se rompe así el esquema de la deixis omnitemporal de la verdad general proclamada en el enunciado del refrán y en el enunciado de la máxima, pero se acentúa el grado del compromiso actual del sujeto enunciador con el valor moral del desprendimiento, la honradez y la austeridad. Por eso, Sancho puede pasar más adelante a asumir el contenido de este pseudo-refrán para convertirlo en una especie de lema existencial referido a la austeridad de su propia vida cuando se despide de los duques, después de haber sido gobernador de la ínsula Barataria durante diez días, diciéndoles : «En efecto, yo entré desnudo en el gobierno y salgo desnudo dél, y así podré decir con segura conciencia, que no es poco: «Desnudo nací, desnudo me hallo: ni pierdo ni gano» (II, 57, 1090). Ya había empleado antes el mismo lema en un contexto de comunicación parecido en II, 53, 1065 y en II, 55, 1082. Esta insistencia marca claramente ante el lector un rasgo de la identidad del personaje (efecto-personaje) y es al mismo tiempo una muestra de la polifonía dentro de esta novela porque el autor contrapone (con ironía indirecta) el discurso sincero de Sancho a la artificialidad y a la falsedad del discurso de los duques y de los que les rodean.

Cuando Sancho recurre a este lema existencial, se aleja de la sabiduría impersonal y doxal del refrán para entrar en el campo del pensamiento o de la filosofía personal sobre el sentido de la vida, campo en el que la máxima adquiere su plena significación. Por eso trataremos sobre la filosofía de Sancho, una vez que hayamos expuesto las funciones y los valores de las máximas o reflexiones morales de don Quijote en la interacción dialogada.

\section{MODALIDADES, OBJETIVOS Y EFECTOS DEL EMPLEO DE LA MÁXIMA EN EL DISCURSO DE DON QUIJOTE}

Dado que aquí tratamos de estudiar el funcionamiento de la máxima en el discurso de don Quijote, consideramos a este personaje como la fuente o el origen de una determinada sabiduría o ideología que se enuncia como una verdad universal formulada de una manera categórica por medio de un presente que no se relaciona con el momento de la enunciación sino que tiene un carácter atemporal u omnitemporal. Esa sabiduría remite a ciertos códigos culturales que estaban operando en la sociedad en la época. Como hipótesis de partida diremos, desde una perspectiva global, que la sabiduría que impregna el discurso de don Quijote procede de dos campos o focos contrapuestos a los que hemos hecho alusión más arriba: la sabiduría novelesca de sus lecturas y la sabiduría humanista. La sabiduría humanista remite a la dignidad personal y moral de don Quijote que está más allá de su locura circunstancial. Esta sabiduría debe relacionarse con el humanismo cristiano que Cervantes ha asimilado y que, como hemos señalado anteriormente, guarda relación con ciertas influencias de carácter erasmista. A esas influencias hace alusión Canavaggio matizando lo siguiente: 
En premier lieu, il convient de se prémunir contre le danger de réduire la formation intellectuelle de Cervantès à une sorte de monopole érasmiste. L'héritage humaniste, décanté par lui à travers des filtres que nous ne sommes pas en mesure d'identifier clairement, s'observe plutôt dans ce qu'il conserve de l'aspiration utopique à marier le christianisme avec les lettres humaines, et l'éthique du Christ et des apôtres avec celle de Socrate et de Sénèque: en d'autres termes, un legs qui s'inscrit, mutatis mutandis, dans une acception de l'humanisme qui fait partie de l'usage actuel et vulgaire de ce terme (Canavaggio, 2009: 7).

Don Quijote manifestará en su discurso su sabiduría novelesca o su sabiduría humanista dependiendo de la situación en la que se encuentre y del objetivo perseguido frente a su interlocutor en la interacción dialogada. Así, cuando don Quijote, impulsado por su lectura apasionada de las novelas de caballerías, proclama ante Sancho (II, 20, 208-209) que su misión consiste en resucitar la edad de oro «en nuestra edad de hierro» imitando las grandes hazañas de los caballeros de la Tabla Redonda y otros, su discurso adopta la retórica altisonante de ese tipo de novelas para defender los objetivos de su heroísmo visionario. Aplicando las teorías de Jung (1964: 115-116), podríamos decir que, al haber asumido el noble ideal del heroísmo de los caballeros andantes, don Quijote se siente llamado a cumplir una misión sublime para responder como fiel discípulo al arquetipo del Maestro (que él identifica con el Amadís de Gaula). Esta convicción le produce una inflación psíquica que genera un desdoblamiento inconsciente de su personalidad y una locura visionaria de la que tomará conciencia sólo al final de su recorrido. Pero en medio de su locura visionaria, don Quijote sigue siendo ante todo un individuo generoso que posee una amplia cultura y una concepción optimista de la condición humana muy cercana a la sabiduría del humanismo renacentista ${ }^{24}$. El lector puede percibir de manera patente esta sabiduría en muchas de sus intervenciones cuando se trata de dar consejos o de reflexionar libremente sobre el valor de la libertad, el amor, la hermosura, la poesía, etc. o cuando se trata simplemente de entablar un diálogo didáctico con Sancho, o un diálogo dialéctico abierto entre interlocutores guiados por una relación de cooperación en la búsqueda de la verdad. Una muestra de diálogo dialéctico abierto se puede percibir en el capítulo 12 de la Segunda parte, donde don Quijote y Sancho dialogan sobre el valor iluminador de la comedia como alegoría de la vida. Don Quijote valora a los que componen comedias y a los que las representan porque hacen «un gran bien a la república, poniéndonos un espejo a cada paso delante, donde se ven al vivo las acciones de la vida humana, y ninguna comparación hay que más al vivo nos represente lo que somos y lo

24. Además de los expertos a los que nos hemos referido más arriba (Vilanova, Forcione, Close, Canavaggio, etc.), este tipo de sabiduría (que remite al «humanismo» de Cervantes) ha sido puesta de relieve también por Luis Larroque en La ideología y el humanismo de Cervantes (2001) y por María Dolores Borrell Merlín en su estudio «Aproximaciones a El Quijote: la justicia, la paz, la política» (2006). 
que habemos de ser como la comedia y los comediantes. Como complemento al valor simbólico de la comedia, Sancho le va a proponer a don Quijote la alegoría iluminadora de las piezas del ajedrez:

-¡Brava comparación! -dijo Sancho-, aunque no tan nueva que yo no la haya oído muchas y diversas veces, como aquella del juego del ajedrez, que, mientras dura el juego, cada pieza tiene su particular oficio; y, en acabándose el juego, todas se mezclan, juntan y barajan, y dan con ellas en una bolsa, que es como dar con la vida en la sepultura (II, 12,719).

Los diálogos filosóficos en forma de controversia dialéctica y los diálogos didácticos fueron muy apreciados por los humanistas del Renacimiento y por los erasmistas ${ }^{25}$. Cervantes integra los diálogos dialécticos en el discurso de sus personajes de ficción uniendo lo ético con lo estético, la enseñanza moral y el humor (grotesco, irónico, crítico) llegando así más allá de lo que los humanistas solo habían intuido, porque, como afirma Canavaggio (2009: 12) va a hacer de la creación literaria de entretenimiento una creación autónoma verosímil y abierta a una compleja polifonía ${ }^{26}$. Don Quijote hace gala también de una sabiduría humanista cuando adopta el tono del género oratorio en sus discursos sobre la Edad de Oro (I, 11), y sobre las Armas y las Letras (I, 37, y 38). Así pues, cuando don Quijote formula una sentencia, una máxima o una reflexión argumentada, el punto de vista defendido o el grado de verdad general que contiene el enunciado tendrá que ser evaluado, en primer lugar, por el auditorio o por el interlocutor al que don Quijote se dirige en su interacción verbal. Por eso resulta significativa la interpretación que don Diego de Miranda $^{27}$ (el caballero del Verde Gabán) hace de las palabras de don Quijote en el capítulo 17 de la Segunda parte donde le considera «un cuerdo loco y un loco que tiraba a cuerdo» percibiendo de alguna manera el contraste de su paradójica identidad desdoblada entre la cordura y la locura:

En todo este tiempo no había hablado palabra don Diego de Miranda, todo atento a mirar y a notar los hechos y palabras de don Quijote, pareciéndole que era un cuerdo loco y un loco que tiraba a cuerdo. No había aún llegado a su noticia la primera parte de su historia; que si la hubiera leído, cesara la admiración en que lo ponían sus hechos y sus palabras, pues ya supiera el género de su locura; pero, como no la sabía, ya le tenía por cuerdo y

25. Señalaremos a este respecto los Colloquia de Erasmo, la traducción de los Diálogos de Platón por Marsilio Ficino, el Diálogo de la doctrina cristiana (1529) de Juan de Valdés, el Diálogo de Mercurio y Carón (1529) de Alfonso de Valdés, el Diálogo de la dignidad del hombre (1546) de Fernán Pérez de Oliva, los Coloquios (1547) de Pedro Mexia, etc.

26. Sobre esta cuestión insistiremos más específicamente en la «Conclusión» de nuestro artículo.

27. La descripción que, en el capítulo XVI de la Segunda parte, don Diego de Miranda hace de su propia vida y costumbres podría constituir un ejemplo modélico del hidalgo español «humanista» desde la perspectiva de Cervantes. A este modelo se acercaría la personalidad de don Quijote liberado de su «locura visionaria», es decir desde su identidad de Alonso Quijano, el Bueno. 
ya por loco, porque lo que hablaba era concertado, elegante y bien dicho, y lo que hacía, disparatado, temerario y tonto (II, 17, 768).

Pero, en definitiva, es al lector al que le corresponde inferir el valor de las reflexiones morales y de las máximas de don Quijote teniendo en cuenta también la actitud que el narrador adopta ante ellas y lo que, más allá del narrador, está dando a entender el autor. Así, por ejemplo, comentando lo acertado de las máximas y de los consejos dados a Sancho antes que fuese a gobernar la ínsula, el narrador evalúa con aprecio el buen entendimiento de don Quijote en todo aquello que no se mezclara con la caballería, y esta puede ser también la opinión del autor:

¿Quién oyera el pasado razonamiento de don Quijote que no le tuviera por persona muy cuerda y mejor intencionada? Pero, como muchas veces en el progreso desta grande historia queda dicho, solamente disparaba en tocándole en la caballería, y en los demás discursos mostraba tener claro y desenfadado entendimiento (II, 53,972-973).

Intentaremos ahora poner de relieve el tipo de temas sobre los que don Quijote muestra su sabiduría humanista recurriendo al empleo persuasivo de la sentencia, la máxima moral, el consejo, la definición alegórica o el razonamiento argumentado.

\subsection{Las diversas manifestaciones y funciones de la máxima en el discurso de don Quijote}

Don Quijote recurre a enunciar su sabiduría en forma máxima cuando, ejerciendo una actividad de reflexión filosófica o didáctica, desea extraer de la experiencia de lo contingente y pasajero una verdad permanente, o cuando proyecta sobre lo vivido una verdad universal iluminando su sentido profundo al relacionarlo, por ejemplo, con un valor esencial (ético o moral). En algunas ocasiones, ejerce la reflexión recurriendo al género didáctico-narrativo de la alegoría. Por medio de la alegoría, el locutor intenta hacer percibir al destinatario una verdad universal (abstracta o espiritual) apoyándose en la narración/ descripción de un tema concreto que funciona como comparante metafórico por la vía de la analogía. Hemos visto más arriba cómo don Quijote y Sancho dialogan sobre el valor iluminador de la comedia como alegoría de la vida (II, 12). No podemos detenernos en analizar aquí cómo don Quijote explica al caballero del Verde Gabán la dimensión espiritual de la poesía apoyándose en la personificación alegórica de una «doncella tierna y de poca edad, y en todo estremo hermosa, a quien tienen cuidado de enriquecer, pulir y adornar otras muchas doncellas, que son todas las otras ciencias» (II, 16, 757). Nos limitaremos a señalar que en este diálogo didáctico, don Quijote enuncia dos máximas o reflexiones que contienen un gran valor iluminador. La primera se 
refiere a la misteriosa transformación alquímica que produce la poesía: «Ella es hecha de una alquimia de tal virtud, que quien la sabe tratar la volverá en oro purísimo de inestimable precio». La segunda ilumina la actividad creadora del escritor recurriendo a esta brillante metáfora: «La pluma es lengua del alma: cuales fueren los conceptos que en ella se engendraren, tales serán sus escritos» (II, 16, 759). Con estas reflexiones sobre la poesía y la creación literaria, don Quijote proyecta en su discurso un ethos de hombre sensible y culto del que emana una sabiduría humanista que contrasta fuertemente con su locura visionaria de querer resucitar el heroísmo de la caballería andante.

En otras ocasiones, don Quijote recurre a la facultad persuasiva de la sentencia o de la máxima para ofrecer una sabiduría muy próxima a la cultura popular enunciada como una especie de refrán. Así ocurre, por ejemplo, cuando Sancho descubre que don Quijote ha perdido en una paliza las muelas de abajo, y éste le dice: «Porque te hago saber, Sancho, que la boca sin muelas es como molino sin piedra, y en mucho más se ha de estimar un diente que un diamante» (I, 18, 198). La reflexión en forma de sentencia puede ser simplemente la reformulación de algún refrán no citado como tal, como ocurre, por ejemplo, cuando don Quijote reacciona con optimismo tras la paliza que le han dado unos pastores por haber luchado contra sus ovejas a las que había confundido con un ejército de gigantes:

Sábete, Sancho, que no es un hombre más que otro, si no hace más que otro. Todas estas borrascas que nos suceden son señales de que presto ha de serenar el tiempo y han de sucedernos bien las cosas, porque no es posible que el mal ni el bien sean durables, y de aquí se sigue que, habiendo durado mucho el mal, el bien está ya cerca ${ }^{28}$. Así que no debes congojarte por las desgracias que a mí me suceden, pues a ti no te cabe parte dellas (I, 18,196).

Si la circunstancia lo requiere, don Quijote puede elevar su reflexión hacia la formulación de verdades profundas relacionadas con la dignidad del hombre y con su identidad espiritual, como ocurre por ejemplo en el episodio de los galeotes, cuando al oír la palabra «hechicero», va a defender con vehemencia la libertad del pensamiento y de la voluntad del ser humano: "Aunque bien sé que no hay hechizos en el mundo que puedan mover y forzar la voluntad, como algunos simples piensan; que es libre nuestro albedrío, y no hay yerba ni encanto que le fuerce» (I, 22, 240).

Una función de la máxima en El Quijote consiste en servir de moraleja, de lección o de evaluación global del sentido principal que hay que extraer de una dramática historia. En efecto, como la han mostrado Ricœur (1983-1985), Adam (1992: 56-57) y otros teóricos de la narración, todo relato como puesta

28. Don Quijote reformula aquí algunos refranes bien conocidos como: «Quien no hace más que otro, no vale más que otro»; «No hay mal que cien años dure». Ver a este respecto las notas al pie de página de la edición de Rico (2001). 
en intriga de una historia constituye un ejemplo de comportamiento del que se debe extraer una conclusión que hace pertinente y significativo el sentido global de la historia narrada. La conclusión puede ser formulada como una moraleja en forma de máxima o de sentencia, expuesta normalmente al final del relato (aunque también puede aparecer al principio para motivar el valor de la narración). Si la lección queda implícita, le corresponde al lector extraerla. Pero el personaje también puede hacerlo, como lo hace don Quijote tras la desafortunada historia de la liberación de los galeotes: "Siempre, Sancho, lo he oído decir, que el hacer bien a villanos es echar agua en la mar (I, 23, 248). La función de la moraleja en forma de máxima puede ser observada en el capítulo XX de la Primera Parte, cuando don Quijote y Sancho se encuentran perdidos en plena oscuridad oyendo unos ruidos extraños que a Sancho le producen un miedo atroz. Para luchar contra el miedo y para entretener a don Quijote evitando que se mueva creando peligro, Sancho se pone a narrar un cuento que empieza con una moraleja que orienta y evalúa por anticipado el sentido de la historia: «El bien que viniere para todos sea, y el mal para quien lo fuere a buscar» (I, 20, 212). La narración será interrumpida en ocasiones por don Quijote para introducir él mismo sus propias conclusiones en forma de reflexión moral :

[...] Y fue tanto lo que el pastor la aborreció de allí adelante que, por no verla, se quiso ausentar de aquella tierra e irse donde sus ojos no la viesen jamás. La Torralba, que se vio desdeñada del Lope, luego le quiso bien, más que nunca le había querido.

-Ésa es natural condición de mujeres -dijo don Quijote-: desdeñar a quien las quiere y amar a quien las aborrece. Pasa adelante, Sancho (I, 20,213214).

Otra modalidad que adopta el enunciado de la máxima en el discurso de don Quijote es la de servir como consejo, advertencia o precepto. En esta situación la máxima transmite una enseñanza práctica o una norma de buen comportamiento formulada al mismo tiempo como una verdad universal que tiene valor por sí misma. Asumiendo la facultad de ofrecer consejos y normas de buena conducta, don Quijote aparece ejerciendo la autoridad del sabio o del maestro ante su interlocutor. Lázaro (2001: XVIII) afirma que don Quijote adopta aquí el lenguaje de la «doctrina de avisos de buen gobierno» siguiendo el modelo iniciado por Fray Antonio de Guevara ${ }^{29}$. Normalmente los consejos y preceptos van destinados a Sancho, pero en algunas ocasiones el destinatario es otro personaje, como ocurre, por ejemplo, en el capítulo XVI de la Segunda parte donde don Quijote dialoga con don Diego de Miranda. Este le ha dicho que tiene un hijo que lleva ya seis años en Salamanca «aprendiendo las lenguas latina y griega; y, cuando quise que pasase a estudiar otras ciencias, halléle tan embebido en la de la poesía, si es que se puede llamar ciencia, que 
no es posible hacerle arrostrar la de las leyes, que yo quisiera que estudiara, ni de la reina de todas, la teología» (II, 16, 756). Don Quijote le responderá explicándole su concepción de la poesía (a la que hemos hecho alusión más arriba), pero antes le va a exponer, por medio de una reflexión ofrecida como una verdad universal, su manera de entender lo que son los hijos, y le da unos consejos sobre cómo tratarlos en lo que se refiere a los estudios que deseen emprender: «Y en lo de forzarles que estudien esta o aquella ciencia no lo tengo por acertado, aunque el persuadirles no será dañoso; [...] sería yo de parecer que le dejen seguir aquella ciencia a que más le vieren inclinado» (II, 16, 756).

En los capítulos 42 y 43 de la Segunda parte, dedicados a «los consejos que dio don Quijote a Sancho Panza antes que fuese a gobernar la ínsula», don Quijote asume con seriedad y amor paternal la misión de ser «este tu Catón, que quiere aconsejarte y ser norte y guía que te encamine y saque a seguro puerto deste mar proceloso dónde vas a engolfarte; que los oficios y grandes cargos no son otra cosa sino un golfo profundo de confusiones» (II, 42, 969). Los principios sobre los que Sancho debe orientar su oficio de gobernador serán, según los consejos de don Quijote: el temor a Dios, el conocimiento de sí mismo, el camino de la virtud y el sentido de la justicia. He aquí un ejemplo:

Mira, Sancho: si tomas por medio a la virtud, y te precias de hacer hechos virtuosos, no hay para qué tener envidia a los que los tienen de príncipes y señores, porque la sangre se hereda y la virtud se aquista, y la virtud vale por sí sola lo que la sangre no vale (II, 42, 970).

Don Quijote volverá a formular nuevos consejos a Sancho en la carta que le escribe cuando ya es «gobernador» (ver II, 51). Ahora bien, conviene observar que cuando don Quijote decide educar a Sancho con sus consejos y preceptos para que actúe con honradez y buenos modales en su oficio de gobernador de una ínsula, lo hace desde una actitud de sinceridad, sin saber que su estancia en el palacio de los duques (donde ha sido recibido como un «verdadero» caballero andante tal como se narra en II, 31, 880), los espectáculos y aventuras que allí suceden y el nombramiento de Sancho como «gobernador» de una «ínsula», son, en realidad, engaños, manipulaciones y artimañas tramadas por los duques y sus colaboradores. El lector, sin embargo, sabe que los duques se están burlando de don Quijote y de Sancho, a los que van a someter a toda una serie de pruebas para convertir en objeto de mofa su credulidad bienintencionada. Por eso, el ethos de sinceridad y de honradez de los dos personajes queda reforzado ante el lector, que podrá reaccionar con solidaridad y simpatía ante las burlas que sufren don Quijote y Sancho $^{30}$.

30. Sobre las mistificaciones y engaños en el palacio de los duques encaminados a ridiculizar a don Quijote como estereotipo del «caballero andante», ver Cuenca-Godbert (2009). 
4.2. Sobre la filosofía humanista de algunas máximas inaugurales de don Quijote

Según Maingueneau, la máxima o sentencia inaugural es aquella que presenta al mismo tiempo las características de lo inédito, de lo memorable y también de lo inmemorial: «Le personnage produit du mémorable, c'est-à-dire un énoncé digne d'être consacré, ancien en droit, nouveau en fait» (1992: 18-19). A lo largo del recorrido de sus aventuras y desventuras para hacerse digno del heroico ideal del caballero andante, don Quijote va a formular una serie de máximas o de sentencias inaugurales que responden a diversos objetivos comunicativos. Mencionaremos en primer lugar una sentencia muy significativa (por la filosofía humanista que implica, unida a la responsabilidad individual) formulada por don Quijote en el capítulo 4 de la Primera parte: «Cada uno es hijo de sus obras» (I, 4, 65). Con esta sentencia don Quijote da a entender que el labrador Juan Haldudo (que estaba azotando a un muchacho llamado Andrés), a pesar de no haber recibido «orden de caballería» alguna, podría ser también un «caballero», porque lo importante para ser un caballero no es ser noble sino actuar realizando obras dignas de un caballero, obras que justifican la identidad del auténtico caballero:

-Mire vuestra merced, señor, lo que dice -dijo el muchacho-; que este mi amo no es caballero, ni ha recibido orden de caballería alguna; que es Juan Haldudo el rico, el vecino de Quintanar.

-Importa poco eso -respondió Don Quijote-, que Haldudos puede haber caballeros, cuanto más que cada uno es hijo de sus obras. Así es verdad, dijo Andrés; pero este mi amo, ¿de qué obras es hijo, pues me niega mi soldada y mi sudor y trabajo? (I, 4, 65).

Afirmando que «cada uno es hijo de sus obras», don Quijote rompe esquemas ideológicos y concibe la noción de caballero andante como una identidad de signo moral, ético o espiritual que sólo se puede alcanzar verdaderamente por medio de obras dignas, como las que él mismo se propone realizar para justificar su misión (sujeto implicado). Rodríguez Valle comenta este episodio diciendo: "Así inicia don Quijote las obras de las que será hijo. En su ideal, este refrán será su motivación, pues él no tiene linaje para ser caballero pero lo será por sus obras» (2008: 146). En realidad, no se trata de un refrán sino de la reformulación de una sentencia que Jesús proclama en el Evangelio de San Mateo (7,15-16), cuando refiriéndose a los falsos profetas, dice «por sus obras los conoceréis». Cervantes conecta así a don Quijote con el tema de la responsabilidad moral del individuo, es decir, con lo que Rodríguez Valle llama el tópico de «las obras hacen linaje», que ha sido cultivado por los humanistas del Renacimiento ${ }^{31}$. 
Otra máxima inaugural muy digna de ser tenida en cuenta corresponde al elogio que don Quijote hace del valor de la libertad, cuando él y Sancho han logrado por fin abandonar el palacio de los duques donde habían sido sometidos a una serie de pruebas y de mofas para divertimento de sus ilustres huéspedes. Para don Quijote, todos los agasajos recibidos han sido forzados y no merecidos por méritos propios:

La libertad, Sancho, es uno de los más preciosos dones que a los hombres dieron los cielos; con ella no pueden igualarse los tesoros que encierra la tierra y el mar encubre; por la libertad, así como por la honra, se puede $y$ debe aventurar la vida; $\mathrm{y}$, por el contrario, el cautiverio es el mayor mal que puede venir a los hombres. Digo esto, Sancho, porque bien has visto el regalo, la abundancia que en este castillo que dejamos hemos tenido; pues en metad de esos banquetes sazonados y de aquellas bebidas de nieve me parecía a mí que estaba metido entre las estrechezas de el hambre porque no lo gozaba con la libertad que lo gozara si fueran míos; que la recompensas de los beneficios y mercedes recibidas son ataduras que no dejan cambiar al ánimo libre. ;Venturoso aquel a quien el cielo dio un trozo de pan, sin que le quede obligación de agradecerlo que al mismo cielo! (II, 58, 1094).

Las palabras con las que don Quijote ensalza aquí el valor supremo de la libertad, unido a la dignidad de la persona y situado por encima del valor de la vida misma, constituyen una máxima inaugural, novedosa y razonada, cuyo mensaje se justifica por sí mismo como una verdad supratemporal válida para todas las épocas. En efecto, más allá de las sabias palabras de don Quijote, el contenido fílosófico de esta máxima se presenta como un principio de alcance universal en el cual está implicada la persona misma de Cervantes, su propia experiencia existencial (soldado comprometido por la libertad de la cristiandad en la batalla de Lepanto, prisionero varios años en Argel) y su concepción humanista de la vida. Asimismo, esta defensa de la libertad individual podrá ser siempre proclamada, como un valor supremo por el que se debe aventurar la vida, contra las tiranías, los totalitarismos y los fanatismos de todo tipo. Por eso, el enunciado que dice «por la libertad, así como por la honra, se puede y debe aventurar la vida; y, por el contrario, el cautiverio es el mayor mal que puede venir a los hombres», debe ser considerado como una máxima que apela a la ejemplaridad heroica en la que está implicado el heroísmo del mismo don Quijote, el cual, enunciando este mensaje, se impone para sí lo que el mensaje prescribe para todos ${ }^{32}$.

cosas peores; y cada uno es hijo de sus obras; y debajo de ser hombre puedo venir a ser Papa, cuanto más gobernador de una ínsula» (I, 47, 546).

32. El concepto de «libertad» no debería entenderse aquí solamente como una oposición al concepto de «cautiverio», sino abrirse a un contenido global más amplio en el que caben también la «libertad de pensamiento» y la «libertad de creación». Conviene señalar que, según Luis Rosales, la libertad es «el eje mismo del pensamiento cervantino» (1985:33). En lo referente a la creación literaria, Antonio Rey Hazas afirma que la libertad es «la clave de la poética cervantina» (1990: 369). 
En relación con el valor que don Quijote atribuye a la «libertad», conviene mencionar su defensa de la supremacía de las «armas» sobre las «letras», porque las armas están al servicio del bien supremo de la paz y de la libertad. Esto lo argumentará con un razonamiento bien hilado en el famoso discurso dedicado a «las armas y las letras» (capítulos 37 y 38 de la Primera parte). Este discurso imita la retórica oratoria del género deliberativo planteando ciertos interrogantes sobre un tema problemático para debatirlo y llegar a una conclusión. Aquí don Quijote, para justificar la supremacía de las «armas», va a desarrollar ante su auditorio unos argumentos que se apoyan sobre ciertos principios formulados en forma de máximas que podríamos considerar «inaugurales». El concepto de las «letras» no se refiere a la literatura sino a las leyes sobre las que se rige la sociedad y por cuyo cumplimiento velan los «letrados». El concepto de las «armas» se refiere a los ejércitos que defienden y protegen a una sociedad, es decir, a los soldados en sentido amplio. La argumentación de don Quijote no se basa en una oposición polémica de las «armas» frente a las «letras» (porque ambas están al servicio del bien común de la sociedad), sino en la diferencia que existe entre el «fin» que persiguen las letras y el «fin» que persiguen las armas siendo estas un elemento necesario para que exista la «paz», que es el «mayor bien» de la sociedad:

Hablo de las letras humanas, que es su fin poner en su punto la justicia distributiva y dar a cada uno lo que es suyo, entender y hacer que las buenas leyes se guarden. Fin, por cierto, generoso y alto y digno de grande alabanza, pero no de tanta como merece aquel a que las armas atienden, las cuales tienen por objeto y fin la paz, que es el mayor bien que los hombres pueden desear en esta vida $(\mathrm{I}, 37,273)^{33}$.

La máxima inaugural con la que don Quijote proclama que la paz «es el mayor bien que los hombres pueden desear en esta vida» tiene como sujeto implicado a toda la Humanidad (pues la paz es un bien permanente y necesario para las sociedades de todas las épocas). Don Quijote refuerza a continuación su concepción de la paz presentándola como un bien sagrado relacionado con el mensaje de Jesucristo en el Evangelio. La paz es así una joya muy especial «que sin ella, en la tierra ni en el cielo puede haber bien alguno». Este es el soporte o el garante del razonamiento argumentativo que le permite a don Quijote pasar a proclamar como conclusión que «Esta paz es el verdadero fin de la guerra». Lo cual significa que el fin de las armas supera al fin de las

33. Al poner en boca de don Quijote la diferencia entre las letras y las armas por el fin que cada una de ellas persigue, Cervantes está recurriendo a un principio de Aristóteles que afirma que «todo se define por su fin» (Ética a Nicómaco, III, 7). Recurre también a la definición que Aristóteles hace del fin de la guerra en su libro La Política donde afirma: «La guerra no se hace sino con la mira de la paz; el trabajo no se realiza sino pensando en el reposo; y no se busca lo necesario y lo útil sino en vista de lo bello. [...] La paz es el fin de la guerra, como el reposo lo es del trabajo». (La Política, libro IV, capítulo XIII: De la igualdad y de la diferencia entre los ciudadanos en la ciudad perfecta). 
letras, pues la verdadera paz necesita ser protegida por las armas, es decir por la guerra, si fuera necesaria («que lo mesmo es decir armas que guerra») ${ }^{34}$.

Don Quijote atrae después la atención sobre las muchas miserias que tiene que sufrir el soldado y el poco reconocimiento que merece su valor, mientras que los letrados suelen ser bien premiados. A pesar de todo, son las armas las que hacen posible que las leyes puedan ser respetadas y que las «repúblicas, los reinos, las monarquías y las ciudades» no queden sujetas «al rigor y la confusión que trae consigo la guerra» (I, 38, 446-447).

El discurso de don Quijote sobre la supremacía de las armas frente a las letras causó un buen efecto de persuasión en los que le escucharon porque en él proyecta un ethos de hombre culto, perspicaz y generoso. En efecto, según el narrador, los que habían escuchado a don Quijote pudieron percibir que tenía «buen entendimiento y buen discurso en todas las cosas que trataba» y lamentaban que se haya perdido «en tratándole de su negra y pizmienta caballería» (I, 38, 449).

Podemos pensar que las palabras de don Quijote sobre las miserias de los soldados y su valentía en el combate son, en realidad, los pensamientos de Cervantes cuyas heridas sufridas en la batalla de Lepanto constituyen un gran honor digno de admiración y de respeto, como él mismo señala en el Prólogo a la Segunda parte:

Si mis heridas no resplandecen en los ojos de quien las mira, son estimadas, a lo menos, en la estimación de los que saben dónde se cobraron; que el soldado más bien parece muerto en la batalla que libre en la fuga; y es esto en mí de manera, que si ahora me propusieran y facilitaran un imposible, quisiera antes haberme hallado en aquella facción prodigiosa que sano ahora de mis heridas sin haberme hallado en ella. Las que el soldado muestra en el rostro y en los pechos, estrellas son que guían a los demás al cielo de la honra, y al de desear la justa alabanza (II, Prólogo, 617).

En El Quijote aparecen otras máximas o reflexiones morales, dirigidas normalmente a Sancho, que muestran lo que hemos llamado la sabiduría humanista de Don Quijote y la perspicacia de su espíritu reflexivo y bien formado. Si no se ajustan al esquema de la máxima inaugural, presentan, sin embargo, un razonamiento bien argumentado en el que brilla la luz de la verdad universal ya sea por el contenido psicológico o por el contenido ético que encierra el enunciado. He aquí un ejemplo en el cual define la fuerza pasional del amor y el comportamiento irracional de los enamorados:

-Advierte, Sancho -dijo don Quijote-, que el amor ni mira respetos ni guarda términos de razón en sus discursos, y tiene la misma condición

34. Ver el párrafo que empieza diciendo «Y así, las primeras buenas nuevas que tuvo el mundo y tuvieron los hombres fueron las que dieron los ángeles la noche que fue nuestro día, cuando cantaron en los aires: "Gloria sea en las alturas, y paz en la tierra, a los hombres de buena voluntad», etc. (I, 37, 443-444) 
que la muerte: que así acomete los altos alcázares de los reyes como las humildes chozas de los pastores, y cuando toma entera posesión de una alma, lo primero que hace es quitarle el temor y la vergüenza; y así, sin ella declaró Altisidora sus deseos, que engendraron en mi pecho antes confusión que lástima. (II, 58, 1099).

\title{
5. LA FILOSOFÍA REALISTA DE SANCHO: ENTRE EL REFRÁN Y LA MÁXIMA
}

Ante el contacto con la sabiduría de don Quijote (a quien irá admirando por la cordura de sus reflexiones y consejos, a pesar de los desastrosos resultados que van teniendo sus hazañas), Sancho llegará a cultivar también sus propias convicciones personales y las expresará no sólo apoyándose en la sabiduría popular de los refranes sino también formulando él mismo sus propias máximas y sentencias. Se produce entonces lo que la crítica ha llamado la «quijotización» de Sancho (ver a este respecto: Lázaro Carreter, 2001: XXIV). Vamos a observar ahora cómo Sancho se va forjando una filosofía realista inscrita en la misma experiencia y basada en una concepción de la dignidad personal no exenta de un cierto estoicismo. Esto se puede percibir ya en algunos capítulos de la Primera parte. Así, por ejemplo, tras haber sido apaleado por los galeotes y haberse retirado en Sierra Morena, Sancho le dará a don Quijote unos consejos muy oportunos, que se acercan al enunciado de la sentencia:

\begin{abstract}
-Señor -respondió Sancho-, que el retirar no es huir, ni el esperar es cordura, cuando el peligro sobrepuja a la esperanza, y de sabios es guardarse hoy para mañana y no aventurarse todo en un día. Y sepa que, aunque zafio y villano, todavía se me alcanza algo desto que llaman buen gobierno; así que no se arrepienta de haber tomado mi consejo, sino suba en Rocinante, si puede, o si no yo le ayudaré, y sígame; que el caletre me dice que hemos menester ahora más los pies que las manos (I, 23, 249).
\end{abstract}

En el capítulo 12 de la Segunda parte, después de que Sancho le hablara a don Quijote del simbolismo las piezas del juego del ajedrez como imagen alegórica de la vida humana, don Quijote admira entonces la sagacidad de Sancho y le dice: «Cada día, Sancho -dijo don Quijote-, te vas haciendo menos simple y más discreto». A lo cual Sancho responderá diciendo que si ha mejorado es porque ha aprendido mucho de la conversación con su amo y maestro. Y se lo explica de manera ingeniosa recurriendo al símil de la tierra estéril que, bien estercolada y cultivada, acaba dando buenos frutos:

Quiero decir que la conversación de vuestra merced ha sido el estiércol que sobre la estéril tierra de mi seco ingenio ha caído; la cultivación, el tiempo que ha que le sirvo y comunico; y con esto espero de dar frutos de mí que sean de bendición, tales que no desdigan ni deslicen de los senderos de la buena crianza que vuesa merced ha hecho en el agostado entendimiento mío (II, 12, 720). 
Pero será sobre todo al final de la segunda parte donde Sancho va a mostrar un pensamiento personal con una serie de reflexiones y de máximas donde preconiza una filosofía estoica que exalta la honradez, la vida sencilla y la resignación cristiana ante las adversidades del destino, en consonancia con el lema que ha escogido para definir su integridad moral y que hemos comentado más arriba: «Desnudo nací, desnudo me hallo: ni pierdo ni gano». Siguiendo esta filosofía, se atreverá a dar consejos a don Quijote para que no sufra por haber sido vencido por el caballero de la Blanca Luna y por ver cómo han quedado oscurecidas sus hazañas:

-Tan de valientes corazones es, señor mío, tener sufrimiento en las desgracias como alegría en las prosperidades; y esto lo juzgo por mí mismo, que si cuando era gobernador estaba alegre, agora que soy escudero de a pie, no estoy triste; porque he oído decir que esta que llaman por ahí Fortuna es una mujer borracha y antojadiza, y, sobre todo, ciega, y así, no vee lo que hace, ni sabe a quién derriba, ni a quién ensalza (II, 66, 1167).

A lo cual le responderá don Quijote admirando la filosofía de Sancho («Muy filósofo estás, Sancho [...], muy a lo discreto hablas: no sé quién te lo enseña») y formulando una reflexión más profunda, en la que afirma que las cosas que suceden en el mundo no ocurren por azar «sino por particular providencia de los cielos, y de aquí viene lo que suele decirse: que "cada uno es artífice de su ventura". Yo lo he sido de la mía, pero no con la prudencia necesaria, y así, me han salido al gallarín mis presunciones» (II, 66, 11671168). Ante el argumento de la propia responsabilidad esgrimido por don Quijote (conectando con la máxima «Cada uno es hijo de sus obras» que había formulado en el capítulo IV), Sancho, con perspicacia y sagacidad, le responde que sea consecuente y se castigue a sí mismo por ser el culpable de su propia desventura (II, 66, 1169).

Guiado por su perspicacia, Sancho llega incluso a iluminar las bondades de la misteriosa realidad del «sueño» recurriendo a una serie de metáforas engarzadas (capa/manjar/agua/fuego/frío/moneda/balanza) que avanzan dentro de una frase compleja con ritmo propio siguiendo el fluir del pensamiento:

\footnotetext{
-No entiendo eso -replicó Sancho-; sólo entiendo que, en tanto que duermo, ni tengo temor, ni esperanza, ni trabajo ni gloria; y bien haya el que inventó el sueño, capa que cubre todos los humanos pensamientos, manjar que quita la hambre, agua que ahuyenta la sed, fuego que calienta el frío, frío que templa el ardor, y, finalmente, moneda general con que todas las cosas se compran, balanza y peso que iguala al pastor con el rey y al simple con el discreto. Sola una cosa tiene mala el sueño, según he oído decir, y es que se parece a la muerte, pues de un dormido a un muerto hay muy poca diferencia (II, 68, 1180).
}

Ante una retórica tan florida y certera, don Quijote reacciona con admiración evaluando el discurso de Sancho y percibiendo en sus razonamientos un 
resultado muy positivo de lo mucho que Sancho ha aprendido conviviendo con él. Y lo hace precisamente por medio de un refrán que Sancho suele decir algunas veces:

-Nunca te he oído hablar, Sancho -dijo don Quijote-, tan elegantemente como ahora, por donde vengo a conocer ser verdad el refrán que tú algunas veces sueles decir: «No con quien naces, sino con quien paces» (II, $68,1180)$.

Si don Quijote llega a admirar la elegancia del discurso de Sancho y sus razonamientos, Sancho, por su parte, admirará plenamente la oratoria de don Quijote a quien considera el hombre más sabio del mundo. Por eso, don Quijote no puede ser un loco: «¿Es posible que haya en el mundo personas que se atrevan a decir y a jurar que este mi señor es loco?» (II, 58, 1104).

De la misma manera que se produce una «quijotización» de Sancho a lo largo del relato, también se produce, sobre todo al final de la narración, un acercamiento de la mentalidad visionaria de don Quijote a la filosofía realista de Sancho, que acabará siendo aceptada por don Quijote en los aspectos más vitales y más básicos:

\begin{abstract}
Yo, a lo menos, no pienso matarme a mí mismo; antes pienso hacer como el zapatero, que tira el cuero con los dientes hasta que le hace llegar donde él quiere; yo tiraré mi vida comiendo hasta que llegue al fin que le tiene determinado el cielo; y sepa, señor, que no hay mayor locura que la que toca en querer desesperarse como vuestra merced, y créame, y después de comido, échese a dormir un poco sobre los colchones verdes destas yerbas, y verá como cuando despierte se halla algo más aliviado.

Hízolo así don Quijote, pareciéndole que las razones de Sancho más eran de filósofo que de mentecato (II, 59, 1108).
\end{abstract}

\title{
CONCLUSIÓN
}

Como conclusión a nuestras observaciones sobre la dimensión persuasiva de la máxima y del refrán y su contribución a la configuración del efecto-personaje, podemos afirmar que las diversas modalidades del empleo del refrán por Sancho (punto 3 y sus apartados) hacen perceptible al lector rasgos bien característicos de la identidad de este personaje. El lector puede percibir también que, a través del diálogo con don Quijote y al contacto con su sabiduría humanista, la personalidad de Sancho ha ido madurando y ha pasado de ser un rústico inculto a ser una persona que sabe ejercer su propia reflexión y formarse sus propias convicciones. Estas convicciones implican un pensamiento realista, basado en la experiencia de la vida, y una cierta filosofía estoica, basada en el concepto de honradez y de austeridad. El lector puede deducir de todo esto una imagen global de la identidad de Sancho que responde a las características de un «cristiano viejo» que sabe cultivar el valor 
de la dignidad personal, la honradez, la serenidad y la imperturbabilidad del espíritu. A estos rasgos, el lector añadirá, por otro lado, un evidente proceso de «quijotización» de la personalidad de Sancho, hasta tal punto, que cuando don Quijote ha recuperado la cordura y está a punto de morir, Sancho parece asumir su idealismo visionario como si se hubiera producido en él un desdoblamiento de su personalidad : «Mire no sea perezoso, sino levántese desa cama, y vámonos al campo vestidos de pastores, como tenemos concertado: quizá tras de alguna mata hallaremos a la señora doña Dulcinea desencantada, que no haya más que ver» (II, 74, 1219).

En lo que se refiere al personaje de don Quijote, podemos afirmar que la sabiduría humanista, que inspira sus máximas, sus consejos, sus reflexiones morales y también la oratoria de su discurso sobre las armas y las letras que hemos comentado, constituye ante los ojos del lector un rasgo bien claro de una personalidad recta y generosa. Don Quijote se guía, en efecto, por el principio de la honradez y de la responsabilidad personal, el sentido de la justicia y el ideal de la paz y de la armonía entre los hombres. Estas características chocan con el lado visionario de su personalidad que, por el deseo de imitar las hazañas de los caballeros andantes y el modelo del Amadís de Gaula, ha producido en su mente un desdoblamiento inconsciente. Su locura le ha conducido a creerse un nuevo caballero andante y a emprender toda una serie de disparatadas aventuras chocando con la dura realidad y obteniendo la incomprensión y la mofa de sus contemporáneos. Pero gracias a la profunda sabiduría que contienen sus máximas, sus consejos y sus reflexiones morales (dimensión persuasiva), el lector puede percibir el ethos de rectitud, de generosidad y de optimismo que muestra en su discurso. Por eso mismo, el lector perspicaz no se dejará llevar por las apariencias y, teniendo en cuenta la complejidad del personaje, percibirá una diferencia entre los episodios circunstanciales de la locura visionaria y el trato personal lúcido y recto que dirige sus diálogos con los que le rodean.

Por eso, conviene interpretar bien la lección o la moraleja que el mismo don Quijote extrae al final del recorrido de su búsqueda visionaria del ideal del caballero andante, y que va a suponer una modificación de su desdoblamiento. La lección será formulada con nostalgia valiéndose del simbolismo de un refrán que no es citado como tal sino integrado en el propio discurso y explicado a continuación con plena lucidez para poner de relieve la transformación de su identidad, porque ha llegado a superar la locura visionaria volviendo a ser Alonso Quijano el Bueno:

\footnotetext{
-Señores -dijo don Quijote-, vámonos poco a poco, pues ya en los nidos de antaño no hay pájaros hogaño: yo fui loco, y ya soy cuerdo; fui don Quijote de La Mancha, y soy agora, como he dicho, Alonso Quijano el Bueno. Pueda con vuestras mercedes mi arrepentimiento y mi verdad volverme a la estimación que de mí se tenía, y prosiga adelante el señor escribano (II, 74, 1220).
}

La recuperación de la cordura quiere decir que el recorrido de las hazañas de don Quijote ha sido como una especie de aprendizaje y que el héroe ha 
tenido que pasar por toda una serie de pruebas para llegar a liberarse de la inflación de su conciencia o de la locura que le había producido el desdoblamiento de su identidad.

Pero, como hemos señalado, la toma de conciencia por el personaje de su identidad anterior no anula ni hace desaparecer todos los momentos de reflexión en los que don Quijote, en sus diálogos y discursos, se ha expresado como un sabio humanista. Su sabiduría, su generosidad y su optimismo idealista sobre la armonía entre los hombres han existido en medio de su locura, y antes y después de su locura. Por eso en el último capítulo, el narrador señala lo siguiente sobre la bondad que ha guiado siempre a don Quijote:

Porque, verdaderamente, como alguna vez se ha dicho, en tanto que don Quijote fue Alonso Quijano el Bueno, a secas, y en tanto que fue don Quijote de La Mancha, fue siempre de apacible condición y de agradable trato, y por esto no sólo era bien querido de los de su casa, sino de todos cuantos le conocían (II, 74, 1218-1219).

Lo importante es entonces percibir la personalidad de don Quijote en su profunda y paradójica identidad, como afirma Canavaggio:

En fin de compte, quelles que soient les situations auxquelles il se voit confronté, don Quichotte transcende non seulement la somme des échecs qu'il subit, mais aussi celle des plaisanteries et des mauvais tours, parfois risibles, dont il est la victime. Il nous apparait comme un héros qui persévère dans son être, sans que les malheurs qu'il connaît parviennent à le disqualifier: le protagoniste d'une histoire, le support d'un véritable roman. En ce sens, la folie qui constitue son leit-motiv et fonde sa cohérence le projette au-delà du grand théâtre du monde, de ce royaume de paradoxe où Érasme avait placé l'éthique emblématique de sa «moria» (Canavaggio, 2009: 11).

Apoyándonos en el análisis que hemos realizado sobre la actividad persuasiva de las voces contrapuestas de Sancho y de don Quijote, podemos afirmar también, siguiendo a Canavaggio (2009:12), que Cervantes ha recogido el deseo de renovación o de autenticidad moral de los humanistas erasmistas y de los humanistas amantes de la renovación de la lengua, y lo ha inscrito en el campo del poder iluminador y crítico de la creación literaria. Por este camino va más allá del humanismo erasmista (que criticaba las historias caballerescas por considerarlas falsas y exageradas), porque Cervantes ha sabido convertir la literatura de entretenimiento en una labor de creación autónoma. Esto lo ha conseguido creando con El Quijote una novela moderna (donde el humor y la ironía juegan un papel importante) dentro de la cual se articulan muchos temas heredados del humanismo renacentista, pero sin defender con ellos un determinado sistema de pensamiento sino enfocándolos de una manera abierta por medio de una compleja polifonía donde se contraponen los diversos puntos de vista de los personajes. Por eso, como bien ha expuesto Canavaggio (2005), Don Quijote se ha convertido en un mito 
literario ${ }^{35}$, en una figura ejemplar de alcance universal que sigue inspirando nuevas creaciones literarias que exploran o reescriben ciertos rasgos de su profunda y fascinante identidad.

\section{BIBLIOGRAFÍA CITADA}

Adam, Jean-Michel (1992). Les textes : types et prototypes. Paris: Nathan.

Bizzarri, Hugo (2003). «Los refranes en Cervantes», Boletín Hispánico Helvético. 2, pp. 25-49 [03-Bizarri-1.pdf].

Bajtín, Mijail (1974). La cultura popular en la Edad Media y el Renacimiento. El contexto de François Rabelais. Barcelona: Barral, 1974; reed. Madrid: Alianza, 1987.

Bajtín, Mijail (1986). Problemas de la poética de Dostoievski. México: FCE.

Bajtín, Mijail (1989). Teoría y estética de la novela. Madrid: Taurus.

Bataillon, Marcel (1978). Erasmo y el erasmismo. Barcelona: Crítica.

Bataillon, Marcel (1991). Érasme et l'Espagne. Daniel Devoto (ed.). Genève: Droz, 3 vols.

Bautista Naranjo, Esther (2013). La reescritura del mito de Don Quijote en la novela de lengua inglesa y de lengua francesa de los siglos XIX y XX. Tesis doctoral defendida el 13 de junio de 2013. Universidad de Castilla-La Mancha.

Bordas, Éric (1997). «L'écriture de la maxime dans le récit balzacien», Poétique. 109, pp. 39-53.

Borrell Merlín, María Dolores (2006). «Aproximaciones a El Quijote: la justicia, la paz, la política», Religión y Cultura. LII, pp. 371-382.

Canavaggio, Jean (2005). Don Quichotte. Du livre au mythe. Paris: Fayard.

Canavaggio, Jean (2009). «L'Humanisme de Cervantès». Conferencia. Paris: Lycée Henri IV, disponible en http://www.apfla-cpl.com/telechargement/humacer.doc

Cantera Ortiz de Urbina, Jesús; Sevilla Muñoz, Julia; Sevilla Muñoz, Manuel (2005). La Fraseología de El Quijote. Vermont: The University of Vermont.

Castro, Américo (1925). El pensamiento de Cervantes. Madrid: Imprenta de la Librería y Casa Editorial Hernando, (anejo VI de la Revista de Filología Española), cap. I, pp.18-67. Disponible en http://cvc.cervantes.es/literatura/quijote_antologia/castro.htm

Castro, Américo (1957). Hacia Cervantes. Madrid: Taurus.

Chevalier, Maxime (1979). « Proverbes, contes folkloriques et historiettes traditionnelles dans les œuvres des humanistes parémiologues», en A. Redondo, L'humanisme dans les lettres espagnoles. Paris: J.Vrin, pp. 105-118.

Cervantes, Miguel de (2001). Don Quijote de La Mancha. Francisco Rico (ed.). Barcelona: Crítica.

Close, Antony (2004). «Cervantes: Pensamiento, Personalidad, Cultura», en Francisco Rico (ed.), Miguel de Cervantes, Don Quijote de La Mancha. Barcelona: Galaxia Gutenberg/ Instituto Cervantes/Círculo de Lectores. Disponible en http://cvc.cervantes.es/literatura/ clasicos/quijote/default.htm

Colón Doménech, Germán (2004). «Los adagia de Erasmo en español (Lorenzo Palmireno, 1560) y en portugués (Jerónimo Cardoso, 1570)", Revista de Filología Española. LXXXIV, $1^{\circ}$, pp. 5-27.

35. Sobre las creaciones literarias inspiradas de alguna manera en el mito de Don Quijote, Esther Bautista Naranjo ha defendido en 2013 una brillante tesis doctoral titulada La reescritura del mito de Don Quijote en la novela de lengua inglesa y de lengua francesa de los siglos XIX y XX. Universidad de Casilla-La Mancha. 
Combet, Louis (1971). Recherches sur le «refranero» castillan. Paris: Les Belles Lettres.

Combet, Louis (1997). «La fonction occulte des proverbes dans le Don Quichotte», $\mathrm{Pa}$ remia. 6 , pp. 173-182.

Colombi, María Cecilia (1989). Los refranes en El Quijote: texto y contexto. Potomac: Maryland.

Cuenca-Godbert, Marta (2009). «Don Quichotte, un don quichotte? Déprogrammation d'un stéréotype», Cahiers de Narratologie. 17. Disponible en: http://narratologie.revues. org $/ 1280$

Delgado, Edmundo Ernesto (2000). «Consideraciones en torno al lenguaje en Don Quijote: Bases para una aproximación estilística», Cervantes: Bulletin of the Cervantes Society of America. 20, 2, pp. 53-78. Disponible en http://users.ipfw.edu/jehle/cervante/csa/ articf00/delgado.pdf

Erasmo de Rotterdam (1999). Elogio de la Locura o Encomio de la Estulticia. Madrid: Espasa-Calpe, Colección Austral, [Enchomion moriae seu Laus stultitiae, 1511].

Erasmo de Rotterdam, Adagia (diversas ediciones: 1500-1536).

Erasmo de Rotterdam, Colloquia (diversas ediciones: 1517-1530).

Forcione, Alban K. (1982). Cervantes and the Humanist Vision: A Study of Four Exemplary Novels. Pricenton: Pricenton University Press.

Fournet-Perot, Sonia (2009). «Les proverbes dans "El ingenioso hidalgo don Quijote de La Mancha : des stéréotypes linguistiques et culturels révélateurs de la complexité du message cervantin». Cahiers de Narratologie, 17, pp. 2-16. Disponible en http:// narratologie.revues.org/1288

Gómez-Jordana Ferrari, Sonia (2006). El proverbio: hacia una definición lingüistica. Estudio semántico de los proverbios franceses y españoles contemporáneos. Tesis doctoral defendida en la Universidad Complutense de Madrid.

Hatzfeld, Helmut (1972). «El "Quijote" como obra de arte del lenguaje». Revista de Filología Española, Anejo LXXXIII. Madrid: CSIC.

Herrero Cecilia, Juan (1992). «Mijail Bajtín y el principio dialógico en la creación literaria y en el discurso humano», Suplementos-Anthropos (Materiales de trabajo intelectual), 32. Barcelona: Anthropos, pp. 55-66.

Joly, Monique (1984). "Le discours métaparémique dans Don Quichotte", en François Suard et Claude Buridant (eds.), Richesse du proverbe. Lille: Presses Universitaires de Lille. Vol. II Typologie et fonctions, p. 245-260.

Joly, Monique (1996). Études sur "Don Quichotte". Paris: Publications de la Sorbonne.

Jouve, Vincent (2010). Poétique du roman. Paris: Armand Colin.

Jung, C.G. (1964). Dialectique du Moi et de l'inconscient. Paris: Gallimard.

Larroque Allende, Luis (2001). La ideología y el humanismo de Cervantes. Madrid: Biblioteca Nueva.

Lázaro Carreter, Fernando (2001). «Estudio preliminar: Las Voces del Quijote», Miguel de Cervantes, Don Quijote de La Mancha. Francisco Rico (ed.). Barcelona: Crítica, IXXXV. Disponible en http://cvc.cervantes.es/obref/quijote/introduccion/estudio/default. htm

Lozano-Renieblas, Isabel (2012). «Vitalismo y estética en Cervantes y la libertad», Espéculo, Número especial "Luis Rosales". Disponible en http://www.ucm.es/info/especulo/lrosales/isable lozano html

Maingueneau, Dominique (1992). «Un problème cornélien. La Maxime», Études littéraires. 25, 1-2, pp. 11-22.

Mexia, Pedro (1547). Coloquios. Sevilla: Dominicum de Robertis (imp.).

Núñez, Hernán (1555). Refranes o proverbios en romance, Salamanca: Juan de Cánova (imp.), reeditada en 2001, Edición crítica de L. Combet, J. Sevilla, G. Conde y J. Guía. Madrid: Ediciones Guillermo Blázquez, 2 vols. 
Pérez de Oliva, Fernán (1546). Diálogo de la dignidad del hombre. Alcalá: Juan de Brocar (imp.).

Rabatel, Alain (2004). Argumenter en racontant. Bruxelles: De Boeck.

Rabatel, Alain (2008). Homo narrans. Pour une analyse énonciative et interactionnelle du récit. Tome I : Les points de vue et la logique de la narration. Lambert-Lucas (ed.). Limoges: Lambert-Lucas.

Redondo, Agustín (1979). L'humanisme dans les lettres espagnoles. Paris: J.Vrin.

Rey Hazas, Antonio (1990). «Cervantes, El Quijote y la poética de la libertad», en Actas del I Coloquio Internacional de la Asociación de Cervantistas. Barcelona: Anthropos, pp. 369-380.

Ricœur, Paul (1983-1985). Temps et récit. Paris: Seuil, 3 Vol.

Rodríguez Valle, Nieves (2005). «Paremias en "El Quijote" de 1605 como estrategias literarias», Paremia. 14, pp. 61-70.

Rodríguez Valle, Nieves (2008). «La "creación” de refranes en el Quijote», Paremia. 17, pp. 143-151.

Rosales, Luis (1985). Cervantes y la libertad. Madrid: Ediciones Cultura Hispánica del Instituto de Cooperación Iberoamericana, 2 vols.

Rosenblat, Angel (1971). La lengua del Quijote. Madrid: Gredos.

Schapira, Charlotte (1999). Les stéréotypes en français : proverbes et autres formules. Paris : Ophrys

Sevilla Muñoz, Julia y Cantera Ortiz de Urbina, Jesús (2002). Pocas palabras bastan. Vida e interculturalidad del refrán. Salamanca: Centro de Cultura Tradicional.

Tarnovska, Olga (2005). «Sobre los refranes de El Quijote», Didáctica (Lengua y Literatura). 17, pp. 285-300.

Trueblood, Alan S. (1984). «La risa en el Quijote y la risa de don Quijote», Cervantes. Bulletin of the Cervantes Society of America. 4.1, pp. 3-23.

Valdés, Alfonso de (1529). Diálogo de Mercurio y Carón. Ed. de Rosa Navarro Durán, Madrid: Cátedra, 1999.

Recibido: 24 de septiembre de 2012 Aceptado: 24 de octubre de 2013

\begin{abstract}
Resumen
Con este estudio tratamos de poner de relieve la dimensión persuasiva de la máxima y del refrán en El Quijote de Cervantes relacionando el recurso a la máxima y al refrán con las voces de don Quijote y Sancho como una manifestación significativa de su manera de pensar y de enfocar la realidad de la vida y del mundo, y como una estrategia eficaz que contribuye a producir en la mente del lector el «efecto-personaje». El empleo de la máxima o de la reflexión moral por don Quijote manifiesta un pensamiento personal de alcance universal relacionado con una sabiduría humanista que contrasta con su locura caballeresca. Sancho, por su parte, recurriendo a la sabiduría popular de los refranes para defender la lógica del sentido común, ofrece la imagen de un espíritu perspicaz y sincero. Entre ambos personajes se irá produciendo una influencia mutua que implica una transformación y una especial armonía entre contrarios.
\end{abstract}

Palabras clave: Máxima y refrán en El Quijote; Don Quijote y la sabiduría humanista; narración y argumentación; polifonía ideológica y «efecto-personaje». 
Title: The Persuasive Strategies of the Maxim and the Proverb in Cervantes' Don Quixote and its contribution to the shaping of the Character-effect.

\begin{abstract}
This article is aimed at highlighting the persuasive aspect of maxims and proverbs in Cervantes' Don Quixote. We will draw a connection between the use of maxims and proverbs and the voices of Quixote and Sancho as a meaningful sign of their viewpoint about the reality of life and the world, as well as a functional strategy which contributes to producing the «character-effect» in the reader's mind. Don Quixote's choice of the maxim or moral reflection articulates an individual thought with a universal significance related to a humanist knowledge that opposes his madness about knight-errantry. Sancho, for his part, by employing the popular wisdom of proverbs as a stand for the logics of common sense, causes an impression of a shrewd, sincere mind. Both characters will gradually complement each other, which implies a sense of evolution and an unusual harmony between opposites.
\end{abstract}

Key words: Maxim and proverb in Don Quixote; Don Quixote and humanist knowledge; Narration and argumentation; Ideological polyphony and «character-effect». 